\title{
In-cloud oxalate formation in the global troposphere: a 3-D modeling study
}

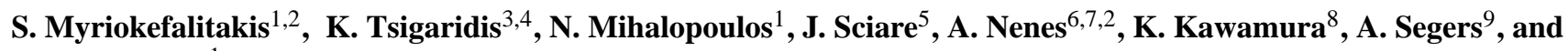 \\ M. Kanakidou ${ }^{1}$ \\ ${ }^{1}$ Environmental Chemical Processes Laboratory, Department of Chemistry, University of Crete, 71003, P.O. Box 2208, \\ Heraklion, Greece \\ ${ }^{2}$ Institute of Chemical Engineering and High Temperature Chemical Processes (ICE-HT), Foundation for Research and \\ Technology Hellas (FORTH), Patras, 26504, Greece \\ ${ }^{3}$ Center for Climate Systems Research, Columbia University, New York, NY 10025, USA \\ ${ }^{4}$ NASA Goddard Institute for Space Studies, New York, NY 10025, USA \\ ${ }^{5}$ Laboratoire des Sciences du Climat et de l'Environnement (LSCE), CNRS/CEA, 91190 Gif sur Yvette, France \\ ${ }^{6}$ School of Earth and Atmospheric Sciences, Georgia Institute of Technology, 311 Ferst Drive, Atlanta, GA 30332-0100, USA \\ ${ }^{7}$ School of Chemical and Biomolecular Engineering, Georgia Institute of Technology, 311 Ferst Drive, Atlanta, GA \\ 30332-0100, USA \\ ${ }^{8}$ Institute of Low Temperature Science, Hokkaido University, Sapporo, Japan \\ ${ }^{9}$ TNO Built Environment and Geosciences, Department of Air Quality and Climate, P.O. Box 80015, 3508 TA Utrecht, \\ The Netherlands
}

Received: 17 December 2010 - Published in Atmos. Chem. Phys. Discuss.: 7 January 2011

Revised: 3 June 2011 - Accepted: 10 June 2011 - Published: 22 June 2011

\begin{abstract}
Organic acids attract increasing attention as contributors to atmospheric acidity, secondary organic aerosol mass and aerosol hygroscopicity. Oxalic acid is globally the most abundant dicarboxylic acid, formed via chemical oxidation of gas-phase precursors in the aqueous phase of aerosols and droplets. Its lifecycle and atmospheric global distribution remain highly uncertain and are the focus of this study. The first global spatial and temporal distribution of oxalate, simulated using a state-of-the-art aqueous-phase chemical scheme embedded within the global 3-dimensional chemistry/transport model TM4-ECPL, is here presented. The model accounts for comprehensive gas-phase chemistry and its coupling with major aerosol constituents (including secondary organic aerosol). Model results are consistent with ambient observations of oxalate at rural and remote locations (slope $=1.16 \pm 0.14, r^{2}=0.36, N=114$ ) and suggest that aqueous-phase chemistry contributes significantly to the global atmospheric burden of secondary organic aerosol. In TM4-ECPL most oxalate is formed in-cloud and less than $5 \%$ is produced in aerosol water. About $62 \%$ of the ox-
\end{abstract}

Correspondence to: M. Kanakidou (mariak@chemistry.uoc.gr) alate is removed via wet deposition, $30 \%$ by in-cloud reaction with hydroxyl radical, $4 \%$ by in-cloud reaction with nitrate radical and $4 \%$ by dry deposition. The in-cloud global oxalate net chemical production is calculated to be about $21-37 \mathrm{Tg} \mathrm{yr}^{-1}$ with almost $79 \%$ originating from biogenic hydrocarbons, mainly isoprene. This condensed phase net source of oxalate in conjunction with a global mean turnover time against deposition of about 5 days, maintain oxalate's global tropospheric burden of $0.2-0.3 \mathrm{Tg}$, i.e. $0.05-0.1 \mathrm{Tg}$ $\mathrm{C}$ that is about $5-9 \%$ of model-calculated water soluble organic carbon burden.

\section{Introduction}

Atmospheric aerosols are composed of water, inorganic salts, crustal material, carbonaceous compounds and trace metals. Organic aerosols (OA) account for a significant fraction of the fine particulate mass in the atmosphere (e.g. Kanakidou et al., 2005; Zhang et al., 2007). However, many uncertainties exist regarding their sources, composition, properties and transformation mechanisms, impending the evaluation of $\mathrm{OA}$ impacts on atmospheric composition, climate, human health and ecosystems (Kanakidou et al., 2005). OA can also affect

Published by Copernicus Publications on behalf of the European Geosciences Union. 
the hygroscopicity of cloud nucleation by modifying cloud condensation nuclei (CCN) number and efficiency (Yu, 2000; Sun and Ariya, 2006).

OA components can be directly emitted in the atmosphere in the particulate phase (primary organic aerosols; hereafter POA) or chemically formed in the atmosphere (secondary organic aerosols; hereafter SOA). A large fraction of "traditional" POA is also semi-volatile, being a dynamic mixture of compounds with vapor pressures that span several orders of magnitude (Robinson et al., 2007). SOA is formed from the gas/particle partitioning of volatile organic compound (VOCs) oxidized by e.g. ozone $\left(\mathrm{O}_{3}\right)$, hydroxyl $(\mathrm{OH})$ and nitrate $\left(\mathrm{NO}_{3}\right)$ radicals (e.g. Kanakidou et al., 2005; Hallquist et al., 2009).

Aerosol Mass Spectrometer (AMS) observations (Zhang et al., 2007; Jimenez et al., 2009) indicate that a large fraction of the ambient OA in the fine mode is chemically processed (oxygenated). The gas-to-particle conversion mechanism is included in many state-of-the-art global atmospheric models (e.g. Tsigaridis and Kanakidou, 2003, 2007; Heald et al., 2005, 2006; Hoyle et al., 2009; Pye and Seinfeld, 2010). In the earlier modeling studies, the OA burden was significantly underestimated (5-100 times in the upper troposphere) compared to observations (de Gouw et al., 2008; Heald et al., 2005; Volkamer et al., 2006). Recent model improvements like consideration of marine OA components (e.g. Myriokefalitakis et al., 2010; Vignati et al., 2010), of the oxidation of intermediate VOC and the semivolatile character of primary OA (Pye and Seinfeld, 2010; Jathar et al., 2011), reduced the discrepancies with observations. Although underestimating OA, most models are actually able to simulate the order of magnitude of OA observations in the troposphere.

Aqueous-phase chemistry provides a complementary pathway for SOA formation to non-aqueous gas-particle partitioning ("traditional" description of SOA) and has the potential to enhance OA concentrations in the atmosphere and particularly in the free troposphere (Blando and Turpin, 2000; Gelencser and Varga, 2005; Sorooshian et al., 2007; Ervens et al., 2008). During SOA formation in the gas-phase, the precursors are mostly high molecular weight (MW) molecules $\left(>\mathrm{C}_{7}\right)$ able to produce semi-volatile compounds. In the case of aqueous-phase SOA formation, the precursors need to be water soluble and therefore can be smaller and oxidized molecules (Volkamer et al., 2007). Their oxidation products have higher O:C atomic ratios than their precursor molecules (Jimenez et al., 2009). During gas-phase oxidation, C-C bonds can often be cleaved, yielding smaller and therefore more volatile compounds. On the contrary, in the aqueous phase $\mathrm{C}-\mathrm{C}$ bonds are preserved, since oxidation of organic compounds by $\mathrm{OH}$ radicals forms multifunctional compounds (Carlton et al., 2007). In addition, condensed-phase $\mathrm{OH}$ and $\mathrm{NO}_{3}$ reactions are shown to enhance O:C ratio in the products (Lim et al., 2010; Herrmann et al., 2005) more than the gas-phase reactions (Jimenez et al., 2009), because the oxidation occurs on low-MW precursors. Such processes can explain the high O:C ratio (close to 1 or even higher) observed in aged ambient aerosols (Aiken et al., 2008; Altieri et al., 2009) and thus bring models closer to observations (Ervens and Volkamer, 2010; Jimenez et al., 2009). One of the most important aqueous-phase products is oxalic acid, $(\mathrm{COOH})_{2}$, which has high $\mathrm{O}: \mathrm{C}$ atomic ratio of 2. Oxalic acid has been reported as an important organic ligand affecting the availability of nutrients, like iron, to the ecosystems (Kaermer, 2003; Reichard et al., 2005). Therefore, understanding its occurrence and fate in the troposphere is of interest for atmospheric chemistry, climate and the biosphere.

Formation of low-volatility organic compounds by multiphase processes has been suggested based on observations during both field (Kawamura et al., 1996; Matsunaga et al., 2003; Liggio and McLaren, 2003; Garcia-Alonso et al., 2006; Volkamer et al., 2007; Hecobian et al., 2010) and laboratory studies (Volkamer et al., 2009; Lim et al., 2010) of glyoxal (CHOCHO; hereafter GLY). GLY is produced via the oxidation of $\mathrm{C}_{n \geq 2}$-hydrocarbons, with a global chemical production estimated to be $45-100 \mathrm{Tg} \mathrm{yr}^{-1}$ (Fu et al., 2008; Myriokefalitakis et al., 2008; Stavrakou et al., 2009). Stavrakou et al. (2009) showed through inverse modeling that only half of the over land observed GLY columns can be understood in terms of identified sources (primary and secondary). GLY is highly reactive in the aqueous phase (Buxton et al., 1997) and has been suggested to participate in heterogeneous reactions producing SOA (Ervens and Volkamer, 2010; Lim et al., 2010). By applying an irreversible uptake $(\gamma)$ of GLY on aqueous particles and cloud drops $\left(\gamma=2.9 \times 10^{-3}\right.$; Liggio et al., 2005a), Fu et al. (2008) and Stavrakou et al. (2009) calculated that about $90 \%$ of GLY is subject to dissolution in atmospheric water (clouds and wet aerosols) contributing to SOA formation by 6.4 to $13 \mathrm{Tg} \mathrm{yr}^{-1}$. However, observations of GLY atmospheric columns from the SCIAMACHY satellite sensor are generally underestimated by chemistry transport models (Wittrock et al., 2006; Myriokefalitakis et al., 2008), in particular over the oceans. Myriokefalitakis et al. (2008) suggested the existence of a source of GLY $\left(\sim 20 \mathrm{Tg} \mathrm{yr}^{-1}\right)$ over the oceans to support GLY columns observed over the tropical oceans. High GLY columns have been also recorded by recent surface-based measurements of GLY over the oceans (Sinreich et al., 2010; Volkamer et al., 2010). Their significance on the GLY budget and involvement in SOA formation remains to be determined.

The main atmospheric reservoirs of liquid water are cloud droplets and wet aerosols; their main difference lies in the amount of liquid water per particle (often well described by the liquid water content, LWC) (Fig. 1). Clouds are formed from condensation of water vapor onto $\mathrm{CCN}$, cover $\sim 60 \%$ of the Earth's surface and occupy about $7 \%$ of the tropospheric total volume (Lelieveld et al., 1989; Pruppacher and Jaenicke, 1995). Clouds provide medium for chemical 

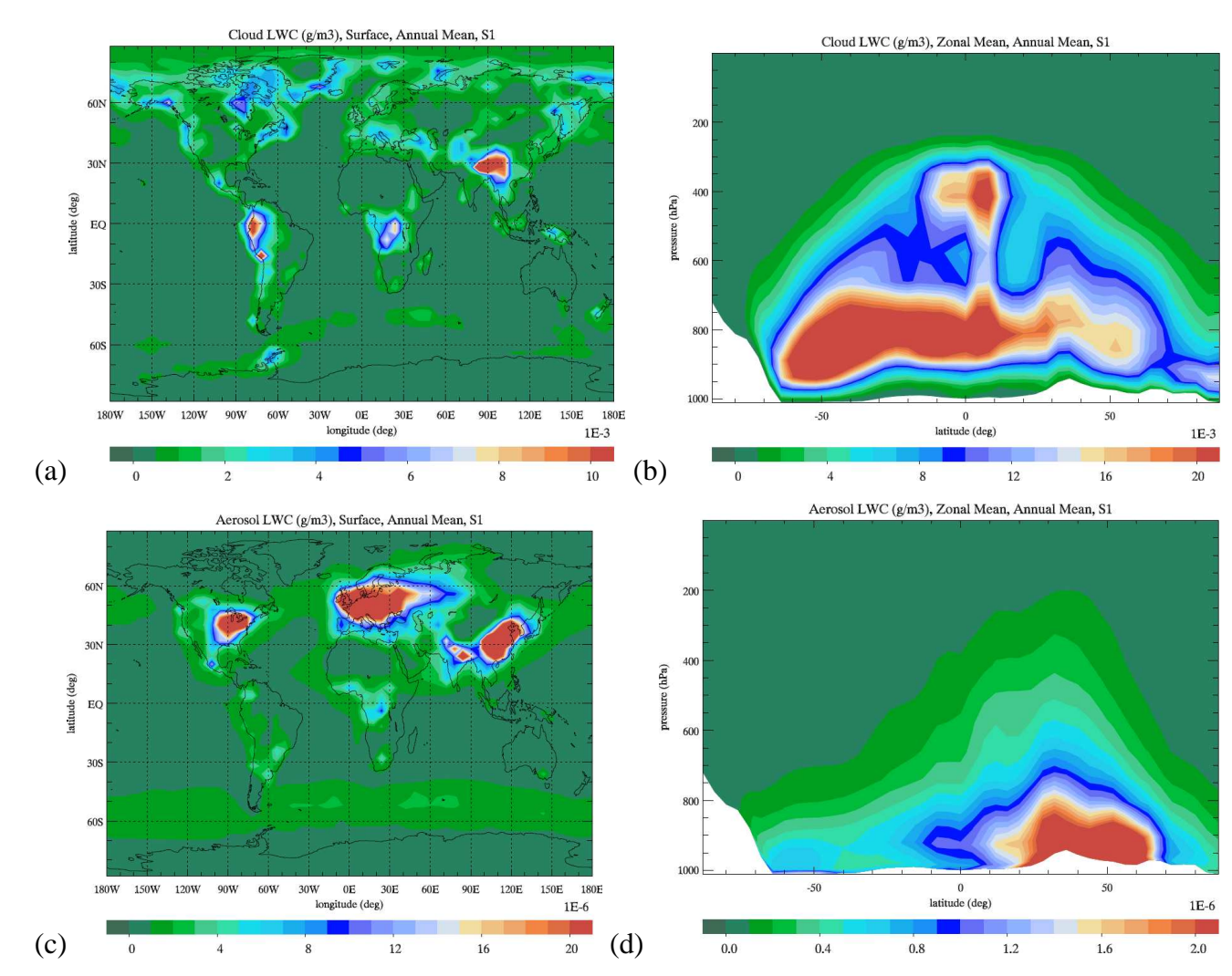

(c)

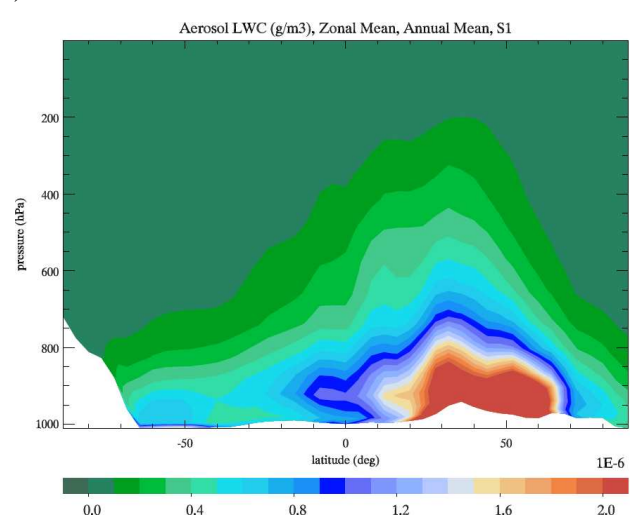

Fig. 1. Annual mean cloud LWC in $\mathrm{g} \mathrm{m}^{-3}$ (a) for surface and (b) zonal mean concentrations for the year 2005, and calculated aerosol LWC in $\mathrm{g} \mathrm{m}^{-3}$ (c) for surface and (d) zonal mean concentrations for the same period.

transformations that are either not taking place, or proceed very slowly in the gas-phase (e.g. non-sea-salt sulfate (nss$\mathrm{SO}_{4}^{2-}$ ) production; Fuzzi et al., 2001). Aerosol water can be about five orders of magnitude less than cloud LWC $(0.1-1$ vs. $10^{-6}-10^{-4} \mathrm{~g} \mathrm{~m}^{-3}$, respectively; Ervens and Volkamer, 2010; Hennigan et al., 2008) therefore the concentration of dissolved substances can vary orders of magnitude between the two systems. In the condensed medium of wet aerosols, organics can react with themselves or with other aerosol components such as sulfate, ammonium, amides, to form sulfur and nitrogen containing organic compounds (Perri et al., 2009; Noziere et al., 2008; Ervens and Volkamer, 2010; Lim et al., 2010).

Water-soluble organic compounds can be transferred and react into atmospheric liquid water, forming lower volatility compounds such as organic acids (Warneck, 2003; Ervens et al., 2004; Lim et al., 2005; Carlton et al., 2006; Perri et al., 2009), oligomers (Tan et al., 2009; Altieri et al., 2006, 2008; Perri et al., 2009) and organosulfates (Liggio et al., 2005b; Galloway et al., 2009). The low volatility organic products remain (at least partly) in the particulate phase after droplet evaporation, contributing to OA mass (Sorooshian et al., 2007, 2010). Hennigan et al. (2009) showed that a substantial amount of gas-phase organic species partition onto aerosol during late morning in the South East US; the organic mass is semi-volatile (but does not evaporate together with the aerosol water) and can contribute substantially, up to $50 \%$ of the total SOA mass, in this region of the globe.

Lim et al. (2005) suggested that carbonyls like glycolaldehyde $\left(\mathrm{HOCH}_{2} \mathrm{CHO}\right.$; hereafter GLYAL) and methylglyoxal $\left(\mathrm{CH}_{3} \mathrm{COCHO}\right.$; hereafter MGLY) could contribute similarly to GLY to the global SOA formation. GLY, GLYAL and MGLY are gas-phase high solubility oxidation products of biogenic and anthropogenic VOCs. In the presence of liquid water, these aldehydes dissolve in the aqueous phase following Henry's law. Hydrated aldehydes are oxidized by $\mathrm{OH}$ and $\mathrm{NO}_{3}$ radicals producing oxalate (hereafter OXL), mostly via glyoxylic acid oxidation (CHOCOOH; hereafter GLX). OXL is a low volatility product that upon cloud evaporation tends to remain in the particulate phase (especially if it is neutralized by e.g. ammonium or sodium).

Lim et al. (2005) and Carlton et al. (2007) presented a chemical scheme of GLY, GLYAL and MGLY in the aqueous phase producing oxalic acid that remains mainly in the particulate phase as OXL. Isoprene is the biogenic hydrocarbon with the highest emissions of about $500 \mathrm{Tg} \mathrm{yr}^{-1}$ (Guenther et al., 1995), followed by terpenes (about $140 \mathrm{Tg} \mathrm{yr}^{-1}$; Guenther et al., 1995), which are the main precursors of 
light aldehydes in the atmosphere like GLY, GLYAL and MGLY (Myriokefalitakis et al., 2008). Box model calculations by Lim et al. (2005) suggested that cloud processing of isoprene contributes to at least $1.6 \mathrm{Tg} \mathrm{yr}^{-1}$ on the global biogenic SOA production.

OXL is globally the most abundant dicarboxylic acid with concentrations ranging from tens of $\mathrm{ng} \mathrm{m}^{-3}$ in remote locations (Sciare et al., 2009) to hundreds of $\mathrm{ng} \mathrm{m}^{-3}$ in urban regions (Kawamura and Ikushima, 1993; Sorooshian et al., 2007; Legrand et al., 2007) and up to more than $1 \mu \mathrm{g} \mathrm{m}^{-3}$ in highly forested areas like the Amazon basin (Falkovich et al., 2005) and Central Africa (Ruellan et al., 1999). Low molecular weight dicarboxylic acids are recognized as ubiquitous aerosol constituents (Kawamura and Kaplan, 1987; Kawamura and Ikushima, 1993; Sempéré and Kawamura, 1994; Kawamura et al., 1995a,b; Kawamura and Sakaguchi, 2009), contributing to a few percent on the water soluble mass (Sorooshian et al., 2007, 2010). The observed correlation between nss- $\mathrm{SO}_{4}^{2-}$ and $\mathrm{OXL}$ at various locations denotes a common formation pathway (Yu et al., 2005; Sorooshian et al., 2006), most probably associated with aqueous-phase chemistry. Modeling studies also support the in-cloud oxalic acid formation (Warneck, 2003; Ervens et al., 2003, 2004; Lim et al., 2005, 2010) from GLY (Carlton et al., 2007) and other "GLY-like" gas-phase precursors like GLYAL (Perri et al., 2009) and MGLY via pyruvic acid $\left(\mathrm{CH}_{3} \mathrm{COCOOH}\right.$; hereafter PRV) oxidation (Altieri et al., 2008).

Primary sources, albeit weak, have also been identified for oxalic acid. Kundu et al. (2010a,b) reported high concentrations of oxalic acid $\left(0.7-2.1 \mu \mathrm{g} \mathrm{m}^{-3}\right)$ in Amazonian aerosols during biomass burning season. Biomass burning can be an important process for the emission of oxalic acid and its precursors to the atmosphere, in addition to the secondary production by photochemical oxidation of biogenic VOC. Moreover, Yamasoe et al. (2000) showed that OXL accounts for about $0.1 \%$ of the total aerosol mass emitted during the burning processes. Schmidl et al. (2008) found that the average concentration of OXL in smoke from the burning of wood ranges between $0.1-0.3 \%$ of the total emitted mass and was about 400 times lower compared to OC emitted masss. Incomplete combustion of aromatic hydrocarbons (benzene, toluene, naphthalenes, and others) in gasoline engines could be also a potential primary source of atmospheric diacids, with oxalic acid concentrations accounting for almost 25$50 \%$ of the total dicarboxylic acid emitted mass (Kawamura and Kaplan, 1987). Nevertheless, vehicle exhaust is not expected to be a significant primary source of oxalic acid in the atmosphere (Huang and $\mathrm{Yu}, 2007$ ).

In the current study we present the first 3-dimensional chemistry-transport modeling (CTM) study of occurrence and fate of oxalate in the global troposphere. The temporal and spatial OXL distributions are simulated using the 3dimensional global CTM, TM4-ECPL, coupled with a multiphase chemistry module. Section 2 describes the modeling tool and the simulations that have been performed for this study. The OXL global budget calculations are presented in Sect. 3 where the contributions of biogenic and anthropogenic sources to OXL chemical production are distinguished and the impact of the OXL removal processes taken into account by the model is discussed. In Sect. 4 the computed OXL distributions are presented and compared, in Sect. 5, with observations of OXL available in literature to evaluate model uncertainties. The implications of the findings for the OA global budget are discussed in Sect. 6 .

\section{Model description}

The chemistry-transport global model TM4 is used for the present study (van Noije et al., 2004). The model version applied here (TM4-ECPL) contains a comprehensive gas-phase chemistry mechanism (Myriokefalitakis et al., 2008) and organic aerosol parameterizations from Tsigaridis et al. (2006), Tsigaridis and Kanakidou (2007) and Myriokefalitakis et al. (2010). Gas-particle partitioning of inorganic components is solved using the ISORROPIA II aerosol thermodynamics model that also calculates aerosol water content (Nenes et al., 1998; Fountoukis and Nenes, 2007). The resolution of TM4-ECPL is 34 vertical hybrid layers from the surface to $0.1 \mathrm{hPa}$ and $4^{\circ} \times 6^{\circ}$ horizontal resolution in latitude and longitude, using a time-step of 1 hour. In this study, the meteorological fields come from ECMWF (European Center for Medium-Range Weather Forecasts) operational data for year 2005 and are updated every $6 \mathrm{~h}$ using short range forecasts over 6 or $12 \mathrm{~h}$.

\subsection{Emissions}

TM4-ECPL uses the monthly average $1^{\circ} \times 1^{\circ}$ gridded VOC, nitrogen oxides $\left(\mathrm{NO}_{\mathrm{x}}\right)$, carbon monoxide $(\mathrm{CO})$ and biomass burning trace gas (biogenic and anthropogenic) emissions from the POET database (Granier et al., 2005) for the year 2000. Biomass burning emissions of carbonaceous aerosols for the respective year are adopted from the Global Fire Emissions Database version 2 (GFED v2; Van der Werf et al., 2006). Marine emissions of POA, hydrocarbons and sea-salt particles, are calculated online as presented in Myriokefalitakis et al. (2010). Dust emissions from AEROCOM (Aerosol Comparison between Observations and Models; Dentener et al., 2006) updated to year 2005 (E. Vignatti, personal communication, 2008) are also used.

\subsection{Organic aerosol formation pathways}

With the exception of the SOA formation from multiphase chemistry that is presented here, all other OA parameterizations have been published in detail previously. The most detailed references are Tsigaridis et al. (2006) and Myriokefalitakis et al. (2010). Briefly, TM4-ECPL accounts for soluble and insoluble forms of anthropogenic and marine primary OA that is ageing chemically by reaction with $\mathrm{O}_{3}$ 
as described in Tsigaridis and Kanakidou (2003). SOA is chemically formed by gas phase oxidation of terpenes and other reactive volatile organics (represented by a- and bpinenes), isoprene and aromatics (represented by toluene and xylene) and dimethylsulfide. For the SOA formation from gas phase oxidation of volatile organics the two-product model has been adopted accounting for the $\mathrm{NO}_{\mathrm{x}}$ dependent SOA formation (Tsigaridis et al., 2006). SOA is also allowed to age chemically by reaction with $\mathrm{OH}$ radical as in Tsigaridis and Kanakidou (2003). Accounting also for the primary OC and its aged forms, TM4-ECPL uses a total of 19 tracers to simulate organic aerosol components that are grouped in 8 major categories: SOA from anthropogenic volatile organics (SOA a), SOA from biogenic volatile organics (SOA b), marine SOA (SOA ocean that includes methanesulfonic acid (MSA), Marine Amines Salts and SOA from marine isoprene and terpenes), Oxalate (OXL), aged SOA, primary anthropogenic OC, primary marine OC. All input parameters adopted for the primary and secondary organic carbon (OC) parameterizations are presented in Myriokefalitakis et al. (2010).

\subsection{Aqueous-phase chemistry scheme}

The aqueous phase chemical mechanism in TM4-ECPL is based on recently published box modeling studies (Ervens et al., 2004; Lim et al., 2005; Herrmann et al., 2005; Sorroshian et al., 2006; Carlton et al., 2007; Ervens and Volkamer, 2010). Chemical production of OXL occurs only in the aqueous phase, as there are no known gas-phase chemical reactions that produce the compound. In the presence of cloud droplets, formaldehyde $\left(\mathrm{CH}_{2} \mathrm{O}\right)$, GLYAL, GLY, MGLY, $\mathrm{HCOOH}, \mathrm{CH}_{3} \mathrm{COOH}$ and PRV are transferred from the gas to the aqueous phase, where GLYAL, GLY, MGLY and $\mathrm{PRV}$ are oxidized by $\mathrm{OH}$ and $\mathrm{NO}_{3}$ radicals to produce OXL via GLX oxidation. In the presence of clouds, GLX and OXL are considered to be dissolved in the aqueous phases whereas in the absence of clouds or after cloud evaporation they reside entirely in the particulate phase. This approximation might result in an overestimate of OXL for realistic conditions since low levels of OXL have been also observed in the gas phase (Baboukas et al., 2000).

The aqueous-phase reactions taken into account in the model are listed in Table 1, together with the adopted reaction rates. The $\mathrm{pH}$-dependence of aqueous-phase chemistry is considered via the equilibrium reactions given in Table S1 (Supplement). In TM4-ECPL, in-cloud $\left[\mathrm{H}^{+}\right]$concentration is calculated from the strong acids and bases as

$$
\left[\mathrm{H}^{+}\right]=2\left[\mathrm{SO}_{4}^{2-}\right]+\left[\mathrm{MS}^{-}\right]+\left[\mathrm{HNO}_{3}\right]+\left[\mathrm{NO}_{3}^{-}\right]-\left[\mathrm{NH}_{4}^{+}\right]
$$

$\left(\mathrm{HNO}_{3}\right.$ is nitric acid, $\mathrm{NO}_{3}^{-}$is nitrate ion and $\mathrm{NH}_{4}^{+}$is ammonium ion). For $\mathrm{pH}>4.3$ the dissolution and subsequent dissociation of $\mathrm{CO}_{2}, \mathrm{SO}_{2}$, and $\mathrm{NH}_{3}$ are also taken into account (Jeuken et al., 2001). For the present study OXL is also considered.
The inorganic composition, phase state (solid/liquid phase) speciation, aerosol water, and $\mathrm{pH}$ are obtained from the ISORROPIA II aerosol thermodynamic equilibrium model (Fountoukis and Nenes, 2007). ISORROPIA in TM4ECPL does not include water uptake by organics, and the organic phase is assumed not to contribute to aerosol water. Neglecting the contribution of organics to the hygroscopicity parameter, $\kappa$, leads to an underestimation of the aerosol $\kappa$ by $20-30 \%$ for an aerosol with organic mass fraction of $80 \%$, however drops to $10 \%$ or lower for mass fraction of $60 \%$ or lower. Based on the OA levels and contributions to the total aerosol mass calculated by TM4-ECPL, this approximation is expected to produce some underestimation in aerosol water and hence underestimation in OXL formation, only in the heart of the Amazon boundary layer. Outside the boundary layer, the contribution of WSOC to total aerosol mass is small, hence its associated water uptake is at most a few percent. Such organic water uptake is within the uncertainty of ZSR (Zdanovskii-Stokes-Robinson approach, with the basic assumption that the quantities of water associated with each solute are additive) for most of the atmosphere. ZSR that is used to predict water uptake in ISORROPIA-II has an estimated error of $\sim 10 \%$.

The partitioning between the gas and aqueous phases of $\mathrm{O}_{3}, \mathrm{OH}, \mathrm{NO}_{3}$ and $\mathrm{HO}_{2}$ radicals, $\mathrm{HNO}_{3}, \mathrm{SO}_{2}, \mathrm{SO}_{4}^{2-}$, hydrogen peroxide $\left(\mathrm{H}_{2} \mathrm{O}_{2}\right), \mathrm{CH}_{2} \mathrm{O}$, GLY, GLYAL, MGLY, $\mathrm{HCOOH}, \mathrm{CH}_{3} \mathrm{COOH}$, PRV, GLX and OXL is parameterized based on the effective Henry's law for pure water (Table S2; Supplement). For most species, the transfer between the gas and aqueous phases is parameterized using the phase ratio $(\Phi)$. $\Phi$ expresses the amount of gas in a given volume of air that resides in the aqueous phase relative to the amount in the interstitial gas phase (Lelieveld and Crutzen, 1991). Using the phase ratios for each species the partitioning between the gas and aqueous phases is calculated. However, mass transfer limitations are taken into account for species with high reactivity in the aqueous phase (Schwartz, 1986). In the present study, the transfer of $\mathrm{OH}, \mathrm{NO}_{3}$ and $\mathrm{HO}_{2}$ radicals between gas and aqueous phases follows mass diffusion processes (see details in Supplement A1). Furthermore, an effective cloud droplet radius of $5 \mu \mathrm{m}$ over land and of $10 \mu \mathrm{m}$ over oceans is here adopted since the cloud droplet radius has been reported to vary between $\sim 3.6$ and $>16.5 \mu \mathrm{m}$ for remote clouds, 1 and $15 \mu \mathrm{m}$ for continental and $\sim 1-25 \mu \mathrm{m}$ for polluted clouds (Herrmann, 2003). Use of an effective cloud droplet radius of $5 \mu \mathrm{m}$ both over land and over oceans results in small changes $(\sim 2 \%$ enhancement in computed OXL formation) in TM4-ECPL calculations, indicating low sensitivity of our computed OXL levels to the changes in droplet sizes, in agreement with Lelieveld and Crutzen (1991) who also pointed out that gas-transfer processes are generally much faster than the chemical processes involved. 
Table 1. The aqueous phase chemical mechanism and corresponding rate constants used in TM4-ECPL. Units for the photolysis frequencies are $\mathrm{s}^{-1}$, and for the second order aqueous reactions are expressed in $1 \mathrm{~mol}^{-1} \mathrm{~s}^{-1}$. Reaction rates are taken from Lim et al. (2005), unless referred differently. Reactions rates are calculated as follows: $k=k_{298} \exp \left[-\frac{E}{R}\left(\frac{1}{T}-\frac{1}{298}\right)\right]$

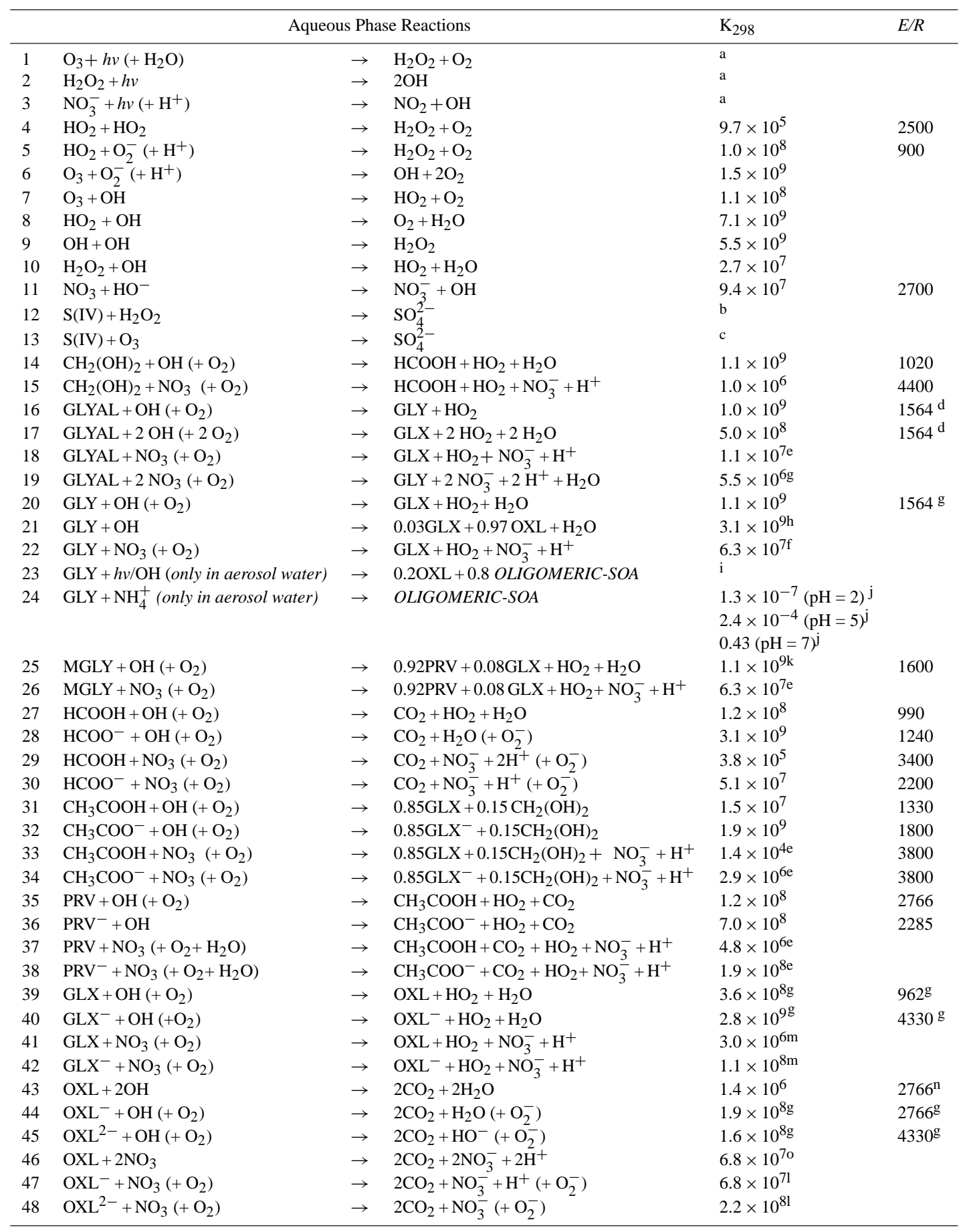

${ }^{\mathrm{a}}$ using the gas-phase photolysis rates (Myriokefalitakis et al. (2008) Supplement.), increased by a factor of 1.5 as recommended by Barth et al. (2003); ${ }^{\mathrm{b}}$ Seinfeld and Pandis (1998); $K=\frac{7.5 \times 10^{7} e^{-4430\left(\frac{1}{T}-\frac{1}{298}\right)}\left[\mathrm{H}^{+}\right]}{1+13\left[\mathrm{H}^{+}\right]} ;{ }^{\mathrm{c}}$ Seinfeld and Pandis $(1998) ; K_{1}=2.410^{4}, K_{2}=3.710^{5 e-530(1 / T-1 / 298)}, K_{3}=1.510^{9} e^{-5280(1 / T-1 / 298)} ;{ }^{\mathrm{d}}$ as for GLY +OH; ${ }^{\mathrm{e}} \mathrm{Herrmann}$ et al. (2005); ${ }^{\mathrm{f}}$ as for MGLY $+\mathrm{NO}_{3} ;{ }^{\mathrm{g}}$ Herrmann (2003); ${ }^{\mathrm{h}}$ lumped reactions based on Carlton et al. (2007); ${ }^{\mathrm{i}}$ photochemical lumped reaction in aerosol water content based on Ervens and Volkamer (2010) with rate of $4 \mathrm{~s}^{-1}$ scaled on the photolysis frequencies of $\mathrm{H}_{2} \mathrm{O}_{2}$, see text; ${ }^{\mathrm{j}}$ Noziere et al. (2009); ${ }^{\mathrm{k}}$ Ervens et al. (2004); ${ }^{1} \mathrm{Herrmann}$ et al. (2000); ${ }^{\mathrm{m}}$ as for glycolic acid from Herrmann et al. (2005); ${ }^{\mathrm{n}}$ as for $\mathrm{OXL}^{-}+\mathrm{OH} ;{ }^{\mathrm{o}}$ as for $\mathrm{OXL}^{-}+\mathrm{NO}_{3}$ 
Table 2. Outline of simulations performed in this study.

\begin{tabular}{ll}
\hline Simulation & Description \\
\hline S1 & $\begin{array}{l}\text { In-cloud OXL formation taking into } \\
\text { account the effect of the ionic strength } \\
\text { of cloud water on GLYAL, GLY and } \\
\text { MGLY. }\end{array}$ \\
\hline S1.1 & $\begin{array}{l}\text { As S1, neglecting the effect of the ionic } \\
\text { strength of cloud water on GLYAL, }\end{array}$ \\
\hline GLY and MGLY. \\
\hline S1.1.1 & $\begin{array}{l}\text { As S1, neglecting the effect of the ionic } \\
\text { strength of cloud water on GLYAL and } \\
\text { MGLY. }\end{array}$ \\
\hline S1.2 & $\begin{array}{l}\text { As S1, neglecting the effect of the ionic } \\
\text { strength of cloud water on MGLY. }\end{array}$ \\
\hline As S1, omitting the temperature \\
dependence of Henry constants.
\end{tabular}

\subsection{Simulations}

Several sources of uncertainty in the predictions have been investigated in the simulations (e.g., the dependence of OXL production on temperature, on the cloud-water $\mathrm{pH}$, on the phase-transfer of the precursor molecules, the potential OXL primary emissions and the OXL chemical formation in aerosol water). For these investigations, simulation S1 has been used as a reference case for simulations S1.1 (S1.1.1, $\mathrm{S} 1.1 .2)$ to $\mathrm{S} 1.5, \mathrm{~S} 2, \mathrm{~S} 3$ and $\mathrm{S} 4$. The differences between theses simulations and $\mathrm{S} 1$ are outlined in Table 2.

The base simulation (S1) assumes that the in-cloud OXL formation is the only source of OXL in the atmosphere. After cloud evaporation, OXL is considered to remain entirely in the aerosol phase. The phase change is governed by Henry's law, where the effective Henry's law constants depend on the aqueous medium composition. Although cloud droplets do not consist of pure water but contain a range of water soluble species e.g. sulfate, ammonium, chloride etc., most of the effective Henry values provided in literature are representative for pure water. Herrmann (2003) presented ionic strength (I) values for remote, continental and polluted clouds ranging between $1 \times 10^{-4} \mathrm{M}$ and $1.7 \times 10^{-1} \mathrm{M}\left(1 \mathrm{M}=1 \mathrm{moll}^{-1}\right)$. Ip et al. (2009) suggested an increase of Henry's law constant of glyoxal (GLY) by 50 times in the presence of sulfate at $\mathrm{I}=3 \times 10^{-2} \mathrm{M}$, compared to pure water. However, they found that increasing I to $2.25 \times 10^{-1} \mathrm{M}$, the effective Henry was enhanced to more than $10^{9} \mathrm{M} \mathrm{atm}^{-1}$. This ionic strength is in the range - close to the higher values though - reported by Herrmann (2003) for polluted clouds. In the present study for the base simulation (S1), in order to represent the effect of ionic strength of atmospheric cloud water, we assume an increase of the effective Henry's law constants (given in Table S2) for GLY, GLYAL and MGLY by 2 orders of magnitude that is within the range of reported enhancement for GLY. Although for MGLY such effect is not known, our assumption can be justified by the similarities in the chemical structure and behavior between GLY and MGLY. For organic acids no such enhancement has been applied.

Nevertheless, the ionic strength and composition of cloud water can certainly be better constrained than the effect of these parameters on the solubility of organics, therefore an additional simulation (S1.1) is carried out that neglects any water ionic composition impact on effective Henry law constants. The phase transfer of the gaseous precursors into the cloud water is critical for the abundance of OXL. Therefore, even though some ionic strength always is present in cloud, S1.1 is used rather as the lower limit for OXL formation. The temperature dependence of Henry law constants can be another significant source of uncertainty in a global modeling study where temperature is spanning over a large range of values. High temperatures are associated with low solubility constants, which imply lower aqueous-phase OXL concentrations near the surface (higher temperatures) and higher in the free troposphere (lower temperatures) than when neglecting the temperature dependence. The temperature effect on species solubility (hence OXL production) has been investigated by an additional simulation (S1.2) where Henry's constants for $298 \mathrm{~K}\left(\mathrm{H}_{298}\right.$; Table S2, Supplement) have been used throughout the model domain. Furthermore, the effect of $\mathrm{pH}$ on OXL formation has been studied analyzing simulation S1.3 in which aqueous-phase partitioning and chemical rates are computed based on a constant $\mathrm{pH}$ (4.5) reflective of a mean value for urban and remote conditions (Herrmann et al., 2000).

Simulation $\mathrm{S} 2$ is similar to $\mathrm{S} 1$, but also considers the (potential) primary combustion sources of oxalic acid (i.e., biomass burning and fossil fuel combustion). Due to the scarcity of available oxalic acid emission factors, biomass burning processes and fossil fuel combustion emissions have been scaled to the organic carbon (OC) observations by Schmidl et al. (2008) (about 400 times lower than that of OC), and the OC emissions from biomass burning and 
Table 3. Global oxalate budget analysis.

\begin{tabular}{|c|c|c|c|c|c|c|c|c|}
\hline & $\begin{array}{l}\text { Atmospheric } \\
\text { Burden } \\
(\mathrm{Tg})\end{array}$ & $\begin{array}{c}\text { Primary } \\
\text { Source } \\
\left(\mathrm{Tg} \mathrm{yr}^{-1}\right)\end{array}$ & $\begin{array}{c}\text { Cloud } \\
\text { Chemical } \\
\text { Production } \\
\left(\mathrm{Tg} \mathrm{yr}^{-1}\right)\end{array}$ & $\begin{array}{c}\text { Cloud } \\
\text { Chemical } \\
\text { Destruction } \\
\left(\mathrm{Tg} \mathrm{yr}^{-1}\right)\end{array}$ & $\begin{array}{l}\text { Particulate } \\
\text { Chemical } \\
\text { Production } \\
\left(\mathrm{Tg} \mathrm{yr}^{-1}\right)\end{array}$ & $\begin{array}{l}\text { Net } \\
\text { Chemical } \\
\text { Production } \\
\left(\mathrm{Tg} \mathrm{yr}^{-1}\right)\end{array}$ & $\begin{array}{c}\text { Dry } \\
\text { Deposition } \\
\left(\operatorname{Tg~yr}^{-1}\right)\end{array}$ & $\begin{array}{c}\text { Wet } \\
\text { Deposition } \\
\left(\mathrm{Tg} \mathrm{yr}^{-1}\right)\end{array}$ \\
\hline S1 & 0.30 & - & 31.8 & 10.6 & - & 21.2 & 1.3 & 19.9 \\
\hline S1.1 & 0.19 & - & 21.2 & 8.0 & - & 13.2 & 0.8 & 12.4 \\
\hline S1.1.1 & 0.20 & - & 21.9 & 8.2 & - & 13.7 & 0.8 & 12.9 \\
\hline S1.1.2 & 0.30 & - & 31.9 & 11.0 & - & 20.9 & 1.3 & 19.6 \\
\hline S1.2 & 0.31 & - & 35.5 & 13.7 & - & 21.8 & 1.3 & 20.5 \\
\hline S1.3 & 0.29 & - & 34.4 & 14.2 & - & 20.2 & 1.3 & 18.9 \\
\hline S1.4 & 0.30 & - & 32.4 & 11.1 & - & 21.3 & 1.3 & 20.0 \\
\hline S1.5 & 0.26 & - & 37.2 & 18.8 & - & 18.4 & 1.1 & 17.3 \\
\hline S2 & 0.31 & 0.1 & 31.8 & 10.6 & - & 21.2 & 1.3 & 19.9 \\
\hline $\mathrm{S} 3$ & 0.33 & 0.1 & 35.0 & 14.2 & 1.5 & 22.3 & 1.4 & 20.9 \\
\hline $\mathrm{S} 4$ & 0.34 & 0.1 & 36.8 & 14.9 & 1.8 & 23.7 & 1.5 & 22.2 \\
\hline
\end{tabular}

anthropogenic combustion processes. The adopted biomass burning OC emissions in TM4-ECPL for the year 2005 amount to roughly $22 \mathrm{TgC} \mathrm{yr}^{-1}$ (GFED v2; Van der Werf et al., 2006). For simulation S2, $0.2 \%$ of these OC emissions $\left(\sim 0.04 \mathrm{TgC} \mathrm{yr}^{-1}\right)$ is assumed to occur in the form of oxalic acid.

Simulation S3 is similar to S2 but considers, in addition, OXL formation into aerosol aqueous phase (Fig. 1c1d). For aerosol water chemistry parameterization in S3, no enhancement of effective Henry's Law is applied. Lim et al. (2010) have shown that the yield of OXL formation from GLY aqueous phase chemistry is highly variable and depends on GLY and OH radical concentrations. Therefore, they recommended the use of explicit chemistry instead of the adoption of a yield in chemistry-transport models where shortlived species concentrations can show variability higher than an order of magnitude. However, they concluded that at cloud relevant GLY concentrations mainly OXL is formed, whereas at aerosol relevant GLY concentrations, GLY-SOA is predominated by oligomers with yields of over $80 \%$. For simplicity, in the present global modeling study (simulation S3) we assume that in-cloud GLY oxidation is producing OXL whereas in aerosol water SOA is produced by GLY oxidation during daytime and via $\mathrm{NH}_{4}^{+}$reactions during nighttime. During nighttime, the $\mathrm{NH}_{4}^{+}$reactions in the aerosol water can be described by a reaction rate constant thatdepends on ammonium activity and $\mathrm{pH}$ and ranges from $1.3 \times 10^{-7} \mathrm{~mol}^{-1} \mathrm{~s}^{-1}$ to $4.3 \times 10^{-1} 1 \mathrm{~mol}^{-1} \mathrm{~s}^{-1}$ (Noziere et al., 2009; Ervens and Volkamer, 2010). The SOA produced in aerosol water during daytime consists of $80 \%$ oligomers and $20 \%$ OXL (by mass, Table 1; Lim et al., 2010). This yield is used as an upper limit of OXL production in the aerosol water. Ervens and Volkamer (2010) suggested that this daytime chemistry in aerosol water is governed by photochemical processes that can be described by a lumped reac- tion rate, which varies between $0.8 \mathrm{~s}^{-1}$ and $7 \mathrm{~s}^{-1}$ depending on the hygroscopicity of seed aerosol.

For this photochemical process, a pseudo-first order reaction rate of $4 \mathrm{~s}^{-1}$ is adopted, which corresponds to an average rate of SOA production on ammonium sulfate seed in agreement with Ervens and Volkamer (2010). To account for the impact of light intensity on this photochemically driven reaction, the rate applied to simulate the glyoxal degradation in the aerosol water was scaled to follow the diurnal variability of the photolysis rate of $\mathrm{H}_{2} \mathrm{O}_{2}$ and to average globally and annually at $4 \mathrm{~s}^{-1}$. In TM4-ECPL, the photolysis rate of $\mathrm{H}_{2} \mathrm{O}_{2}$ in the gas phase varies hourly and is calculated on line by the model as described by Landgraf and Crutzen (1998) and Lelieveld et al. (2002) and based on the IUPAC recommendations (Atkinson et al., 2006). In the absence of light, GLY is considered to exclusively react with ammonium $\left(\mathrm{NH}_{4}^{+}\right)$in the aerosol water (Noziere et al., 2009) producing $100 \%$ SOA (identified by Noziere et al. (2009) to be mostly oligomeric species; B. Ervens personal communication, 2010; Table 1).

Simulation S4 is similar to S3 but also considers a potential GLY source of $20 \mathrm{Tg} \mathrm{yr}^{-1}$ over the oceans that is the low estimate derived by comparison of our model results with satellite observations (Myriokefalitakis et al., 2008). This source is distributed geographically and monthly based on the difference between the TM4-ECPL modeled and SCIAMACHY observed GLY columns shown in Myriokefalitakis et al. (2008).

\section{Budget calculations}

OXL abundance is strictly connected to the concentration of its aqueous-phase precursors that are both of anthropogenic and biogenic origin. OXL precursors are chemically formed in the aqueous phase or emitted from anthropogenic and 
natural (terrestrial and oceanic) sources. According to simulation S1, the global in-cloud chemical production of OXL equals to about $32 \mathrm{Tg} \mathrm{yr}^{-1}$, corresponding to a net chemical atmospheric source (difference between in-cloud chemical production and in-cloud chemical destruction by $\mathrm{OH}$ and $\mathrm{NO}_{3}$ radicals) of about $21 \mathrm{Tg} \mathrm{yr}^{-1}$. TM4-ECPL (S1) global annual mean OXL burden equals to $0.3 \mathrm{Tg}$, corresponding to a global mean turnover time of about 3 days. Below, we elaborate on the strength of biogenic and anthropogenic sources on OXL formation and also on each separate sink of OXL for simulation S1. Budget calculations for the simulations performed to quantify the uncertainty of our results are presented in Table 3.

\subsection{Biogenic sources}

According to TM4-ECPL calculations (S1), oxidation of biogenic volatile organic compound is responsible for the $79 \%$ of the global OXL chemical production. Isoprene is the most important precursor of OXL, contributing to about $70 \%\left(\sim 22 \mathrm{Tg} \mathrm{yr}^{-1}\right)$ to the global OXL production, followed by terpenes that contribute to about $9 \%\left(\sim 3 \mathrm{Tg} \mathrm{yr}^{-1}\right)$. Note that isoprene and terpenes form OXL through their oxidation products GLY, GLYAL and MGLY. In particular, isoprene oxidation by $\mathrm{OH}$ radicals contributes to the global chemical production of these OXL precursors by almost $59 \%$ for GLY, $83 \%$ for GLYAL and $81 \%$ for MGLY, whereas terpenes account for almost $6 \%, 13 \%$, and $13 \%$ respectively. According to TM4-ECPL calculations, MGLY burden of about $0.1 \mathrm{Tg}$ is about 5 times higher than that of GLY $(0.02 \mathrm{Tg}$; see Myriokefalitakis et al., 2008). MGLY is therefore calculated to be an important OXL precursor in the aqueous-phase, via its oxidation to GLX that further reacts to form OXL (Table 1). Overall, in the TM4-ECPL simulation (S1), OXL is produced by about $56 \%$ from GLY $\left(\sim 18 \mathrm{Tg} \mathrm{yr}^{-1}\right), 20 \%$ from GLYAL $\left(\sim 6 \mathrm{Tg} \mathrm{yr}^{-1}\right)$ and about $24 \%\left(\sim 8 \mathrm{Tg} \mathrm{yr}^{-1}\right)$ from MGLY.

\subsection{Anthropogenic sources}

Anthropogenic hydrocarbons contribute by about $21 \%\left(\sim 7 \mathrm{Tg} \mathrm{yr}^{-1}\right)$ to the global OXL chemical production. TM4-ECPL takes into account the chemistry of ethene $\left(\mathrm{C}_{2} \mathrm{H}_{4}\right)$, propene $\left(\mathrm{C}_{3} \mathrm{H}_{6}\right)$, acetylene $\left(\mathrm{C}_{2} \mathrm{H}_{2}\right)$ and aromatics (benzene, toluene and xylene), which affect OXL abundance through their impact on GLY, GLYAL and MGLY formation (Myriokefalitakis et al., 2008). Aromatics contribute almost $13 \%$ and acetylene almost $21 \%$ to GLY chemical formation. Moreover, according to TM4-ECPL model calculations, ethene contributes almost $4 \%$ to GLYAL production. TM4-ECPL simulations show that propene and aromatics are responsible for about $3 \%$ and $2 \%$ of MGLY global chemical formation, respectively. Alkenes (ethene and propene), acetylene and aromatics (benzene, toluene and xylene) contribute $3 \%\left(\sim 1 \mathrm{Tg} \mathrm{yr}^{-1}\right), 10 \%\left(\sim 3 \mathrm{Tg} \mathrm{yr}^{-1}\right)$ and $8 \%\left(\sim 3 \mathrm{Tg} \mathrm{yr}^{-1}\right)$ respectively to global OXL production.

\subsection{Sinks of oxalate}

In TM4-ECPL, OXL is removed from the atmosphere by $\mathrm{OH}$ and $\mathrm{NO}_{3}$ radical in-cloud oxidation (Table 1), wet and dry deposition. According to model calculations (simulation S1), OXL in-cloud oxidation by $\mathrm{OH}$ radicals consumes about $30 \%\left(\sim 10 \mathrm{Tg} \mathrm{yr}^{-1}\right)$ and $\mathrm{NO}_{3}$ radicals about $4 \%$ $\left(\sim 1 \mathrm{Tg} \mathrm{yr}^{-1}\right)$ of the in-cloud produced amount of OXL. The resulting global mean turnover times of OXL due to in-cloud oxidation by $\mathrm{OH}$ and $\mathrm{NO}_{3}$ radicals are calculated to be about 12 days and 94 days, respectively.

OXL is drastically removed from the atmosphere via wet deposition due to its high water solubility (Table S2; Supplement). TM4-ECPL calculates that about $62 \%$ of OXL is removed from the atmosphere via wet deposition $\left(\sim 20 \mathrm{Tg} \mathrm{yr}^{-1}\right)$. Dry deposition has a smaller impact on OXL abundance, removing about $4 \%$ of OXL $\left(\sim 1 \mathrm{Tg} \mathrm{yr}^{-1}\right)$ on the global scale. The resulting wet and dry deposition global OXL turnover times are calculated to be about 6 days and 83 days, respectively. The global mean lifetime of OXL according to both chemical and physical processes in the atmosphere is calculated to be about 3 days.

\section{Oxalate atmospheric concentrations}

Figure 1 presents the annual mean cloud LWC (Fig. 1, b) and aerosol LWC (Fig. 1c, d) for the year 2005. The mean calculated distributions (S1 simulation) of OXL for the lowest (surface) model level and the zonal mean vertical distribution for December, January and February (DJF) and for June, July and August (JJA) are presented in Fig. 2. OXL concentrations reflect its precursor distributions and LWC abundance and maximize over tropical Africa and the Amazon basin (where abundant biogenic VOC emissions occur). During DJF, OXL calculated concentrations reach $1 \mu \mathrm{g} \mathrm{m}{ }^{-3}$ in the tropics over land. During JJA, because of enhanced photochemistry in the Northern Hemisphere (NH), the model calculates a secondary OXL concentration maximum (0.2$0.4 \mu \mathrm{g} \mathrm{m}^{-3}$ ) in northern mid-latitudes. According to TM4ECPL calculations, the summertime OXL peak in the NH can be attributed to about two times higher aqueous-phase $\mathrm{OH}$ radical production than during winter (Fig. S5 and discussion in the Supplement). Summertime aqueous-phase $\mathrm{OH}$ radical concentrations in the $\mathrm{NH}$ are supported both by higher gasphase $\mathrm{OH}$ radical uptake in the aqueous-phase ( $\sim 2$ times) and by enhanced aqueous-phase $\mathrm{OH}$ production due to more intense in-cloud $\mathrm{H}_{2} \mathrm{O}_{2}$ photolysis ( $\sim 2.5$ times). Note, however, that on the global scale the seasonality is reversed, since the aqueous-phase $\mathrm{OH}$ radical production in June is about $2.5 \%$ lower than in January, which may be attributed to the higher biogenic VOC emissions occurring during the warm 
a)

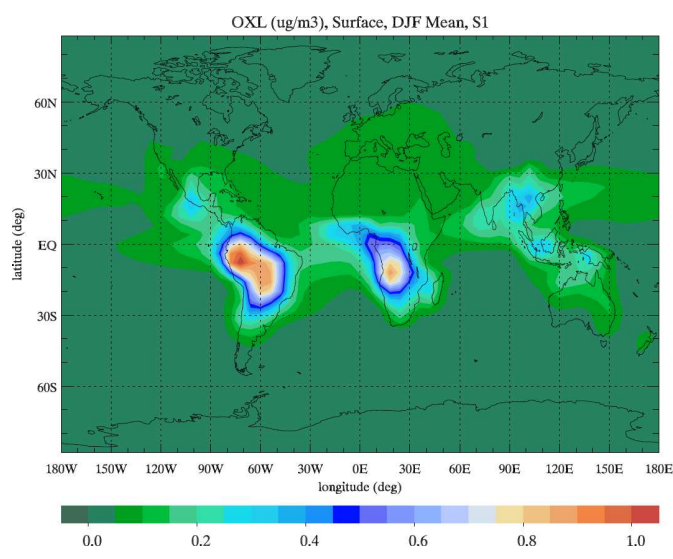

c)

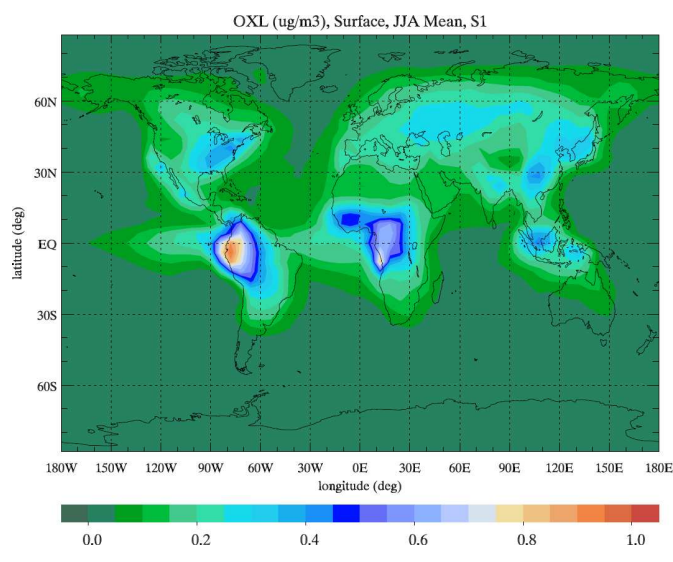

b)

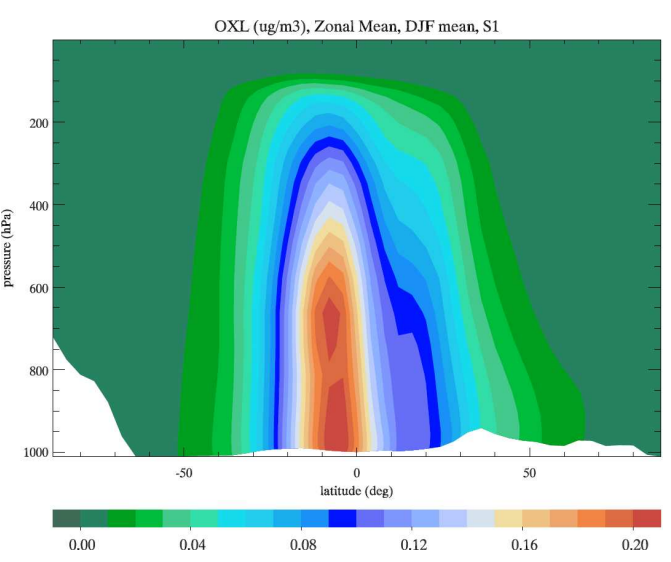

d)

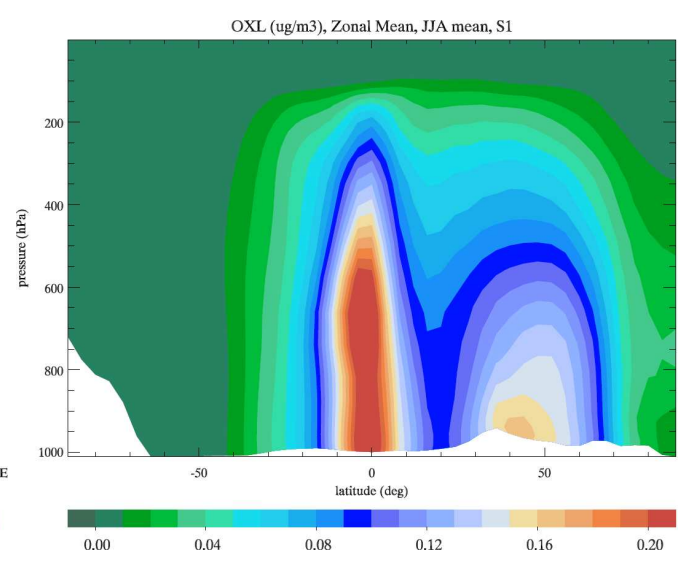

Fig. 2. Calculated OXL surface (a, c) and zonal mean (b, d) concentrations (in $\mu \mathrm{g} \mathrm{m}^{-3}$ ) for Northern Hemisphere winter (DJF mean) (a, b) and Northern Hemisphere summer (JJA mean) (c, d) for S1.

season that suppress $\mathrm{OH}$ radical concentration in the gasphase. Conversely, intense wet scavenging during wintertime keeps OXL concentrations low.

The model also calculates significant OXL concentrations in the free troposphere, although almost 5 times lower than the surface concentrations. In the tropics, biogenic hydrocarbons like isoprene are convectively transported to the mid and high troposphere, where cloud LWC is also high (Fig. 1b). Maximum OXL concentrations $\left(>0.2 \mu \mathrm{g} \mathrm{m}^{-3}\right)$ in the tropical free troposphere (up to $\sim 300 \mathrm{hPa}$ ) are calculated during DJF. The enhanced photochemical production of OXL from the intense biogenic emissions during summertime is reflected on the vertical distribution. During JJA, a second free tropospheric maximum $\left(>0.1 \mu \mathrm{g} \mathrm{m}^{-3}\right)$ is calculated to occur over the mid-latitudes in the $\mathrm{NH}$.

On annual mean basis OXL maximizes over the tropics both at surface (Fig. 3a) and in the free troposphere (Fig. 3b), pointing to the dominance of biogenic sources of OXL precursors, to intensive photochemistry and to strong convective activity in the tropics year around. Non negligible OXL annual mean concentrations are also computed over polluted regions in the Northern Hemisphere near the surface.

As outlined in Sect. 2.2, in addition to OXL aqueous-phase formation, TM4-ECPL calculates the chemical production of SOA components that can be grouped in SOAa, SOAb, SOAocean and aged SOA (Myriokefalitakis et al., 2010). The contribution of each of these groups depends, however, on time and space (Fig. S1; Supplement). OXL, which has a high OM:OC ratio, is calculated to be an important contributor to SOA mass both near the surface (Fig. 3c) and in the free troposphere (Fig. 3d). Figure 3c shows that cloud processing is calculated to be an important source of SOA over the global ocean, where it accounts for $40-50 \%$ of the SOA mass (with the exception of the Southern Ocean and Southern Hemisphere tropical Pacific, where TM4-ECPL predicts a significant contribution of sulfur-containing SOA on total SOA; Myriokefalitakis et al., 2010). Remarkably, although in TM4-ECPL, OXL is mainly driven by isoprene chemistry, 
a)

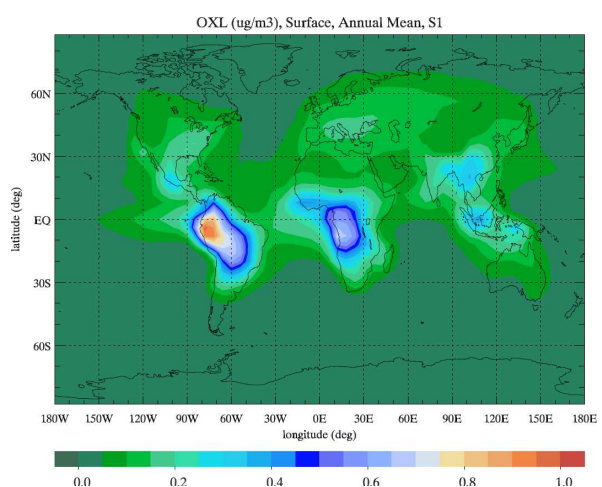

c)

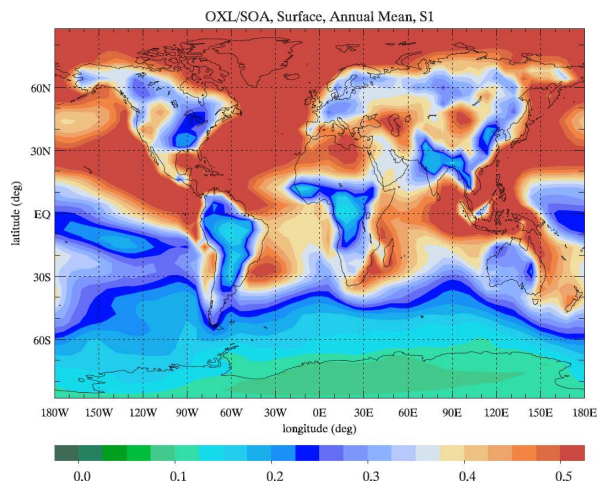

e)

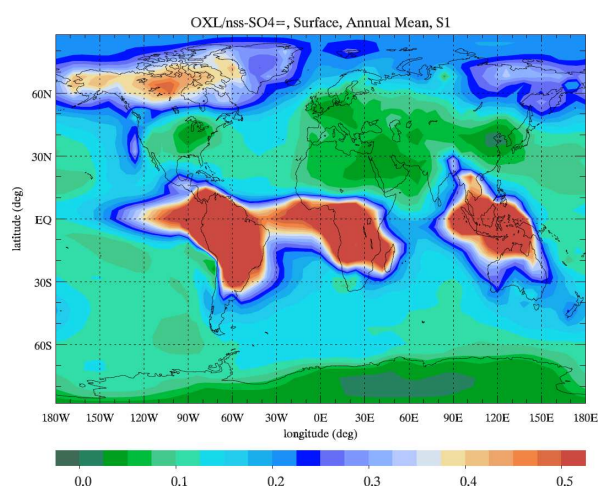

b)

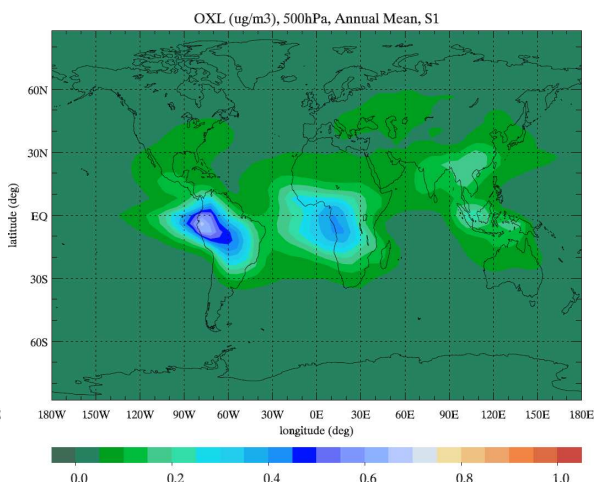

d)

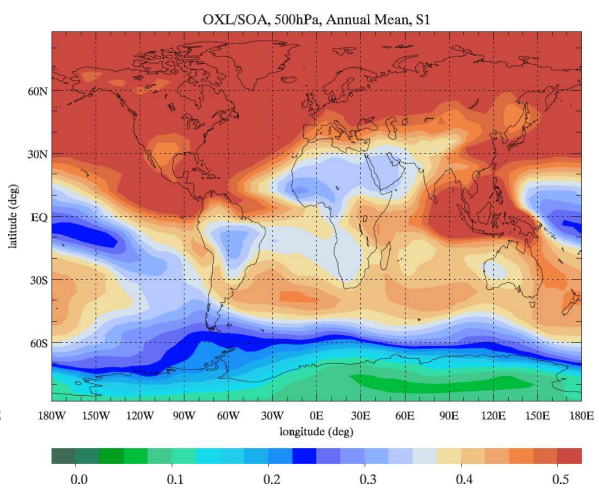

f)

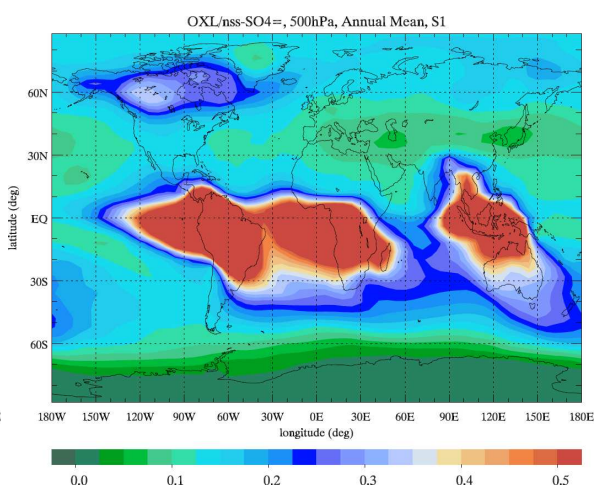

Fig. 3. Calculated annual mean for $\mathrm{S} 1$ of OXL in $\mu \mathrm{g} \mathrm{m}^{-3}$ : (a) at surface (b) at $500 \mathrm{hPa}$; OXL/SOA mass ratio: (c) at surface (d) at $500 \mathrm{hPa}$; $\mathrm{OXL} / \mathrm{nss}-\mathrm{SO}_{4}^{2-}$ mass ratio: (e) at surface, (f) at $500 \mathrm{hPa}$.

high fractions of OXL to SOA total mass are calculated over oceans, possibly due to long range transport of oxidation products of terrestrial biogenic VOC and subsequent cloud processing, as well as to the multiphase processing of the marine VOC emissions. In the free troposphere $(\sim 500 \mathrm{hPa})$, almost everywhere, but especially in the $\mathrm{NH} \sim 50 \%$ of SOA is calculated to consist of OXL.

In Fig. 3e, the OXL concentrations are compared with those of nss- $\mathrm{SO}_{4}^{2-}$, which is also partly a cloud-processing product and a major contributor to cloud condensation nuclei activity. The OXL to nss-SO $\mathrm{SO}_{4}^{2-}$ mass ratios shown in Fig. 3e indicate that nss- $\mathrm{SO}_{4}^{2-}$ is about 9 times higher than OXL in terms of mass in the $\mathrm{NH}$ continental polluted regions but not in the tropics, where OXL reaches half the mass of nss$\mathrm{SO}_{4}^{2-}$ over terrestrial biogenic sources (e.g., Amazon Basin and Central Africa). A similar pattern between the OXL concentrations and $\mathrm{SO}_{4}^{2-}$ is also predicted for $500 \mathrm{hPa}$ (Fig. 3f), although with slightly higher OXL to nss- $\mathrm{SO}_{4}^{2-}$ mass ratios over larger areas. This also depicts the different precursor sources of these two aerosol components. Although OXL 
and nss- $\mathrm{SO}_{4}^{2-}$ correlate both in the observational $\left(r^{2}=0.44\right)$ and in the TM4-ECPL simulated dataset $\left(r^{2}=0.53\right)$, about $30 \%$ higher slope (mean $\mathrm{OXL} / \mathrm{SO}_{4}^{2-}$ mass ratio; Fig. S2, Supplement) and about 2 times higher intercept are derived from the observations than reproduced by the model. The correlation points to the importance of multiphase chemistry for both aerosol components but might also indicate an underestimation of the sources or/and an overestimation of sinks of OXL by TM4-ECPL.

The annual mean total OC distribution as computed by our model is depicted in Fig. S1 (Supplement). Comparison with available observations of OC for the year 2005 shown in Fig. S3 (Supplement) indicates roughly an overall underestimate of OC levels by $50 \%$, mostly occurring over urban regions. The contribution of the major OC components to the computed total OC is also provided in Fig. S1. The OXL contribution to the total WSOC amount is depicted in Fig. 4; about $20 \%$ of the total WSOC over oceanic regions, mainly in the tropical Pacific Ocean, both at surface and the free troposphere (Fig. 4a, b). However, high OXL contribution is not necessarily tied to high absolute levels of OXL, since over ocean SOA levels are significantly lower than over land. Zonal mean OXL (expressed in OC) to WSOC fraction, presents a maximum over the tropics $(\sim 15 \%)$, where high biogenic emissions and LWC occur. Moreover, a second maximum over the $\mathrm{NH}$ is seen (more than $10 \%$ ), which depicts the relative importance of OXL formation over anthropogenically influenced areas. Note however, that in the present study the in-cloud OXL formation is calculated to be mostly biogenically driven, since potential OXL formation from other pathways like photo-ageing of OA (Eliason et al., 2003) and/or aqueous-phase oxidation of longer chain carboxylic acids to shorter diacids (Legrand et al., 2007), which could form OXL, especially over anthropogenically influenced regions (i.e in the $\mathrm{NH}$ ), are not currently included in the present study.

\section{Comparison with observations}

The ability of the model to reproduce the seasonality and levels of OXL is investigated in Fig. 5, which shows the comparison of OXL monthly mean observation in bulk or $\mathrm{PM}_{10}$ aerosol with the TM4-ECPL simulations. OXL observations include measurements at the Finokalia atmospheric monitoring station of the University of Crete (Mihalopoulos et al., 1997) in the Eastern Mediterranean, Amsterdam Island (Sciare et al., 2009) in the Southern Indian Ocean, Mace Head Atmospheric Research Station on the west coast of Ireland (Jennings et al., 1997) and the CARBOSOL sites in Europe (Legrand et al., 2007).

TM4-ECPL is able to reasonably simulate OXL concentrations and their seasonal variation for most locations. Computed OXL concentrations show strong seasonal dependence, with the maxima occurring during the warm season. How- ever, TM4-ECPL simulation S1 appears to underestimate winter OXL concentrations, likely due to either (i) missing OXL primary sources (tentatively taken into account in S2), or (ii) deficient parameterization of OXL formation in the aqueous-phase (tested in S3), or (iii) missing OXL precursors abundance (tentatively accounted for in S4). The high photochemical activity and enhanced precursor emissions during summertime result in more efficient OXL formation in the aqueous phase. Analysis of variance (ANOVA) applied on the monthly mean data depicted in Fig. 5 for all simulations and each station shows that the model reproduces reasonably $\left(0.1<r^{2}<0.7\right)$ the seasonality at most studied locations (Table S4, Supplement) except at Azores and K-Pustza stations. There, the model fails to reproduce the OXL observation variability, most probably due to important contribution from unaccounted regional sources like OXL formation from the degradation of higher fatty acids or in the polluted atmosphere.

Finokalia, located on the northern coast of Crete, is a site representative for the background atmospheric composition of the Eastern Mediterranean (Mihalopoulos et al., 1997; Kouvarakis et al., 2002). The Eastern Mediterranean is the receptor of transported pollution and subject to intensive photochemistry, but also affected by terrestrial and marine biogenic local emissions. Maximum monthly mean OXL concentrations are observed during summer ( $\sim 270 \pm 100 \mathrm{ng} \mathrm{m}^{-3}$ in July; Fig. 5a) and minimum during autumn $\left(\sim 55 \pm 40 \mathrm{ng} \mathrm{m}^{-3}\right.$ in October; Fig. 5a) in 2005. Koulouri et al. (2008) showed strong correlations between OXL and ammonium $\left(\mathrm{NH}_{4}^{+}\right)$, nitrate $\left(\mathrm{NO}_{3}^{-}\right)$and nss- $\mathrm{SO}_{4}^{2-}$, which indicate secondary heterogeneous formation of OXL in this region. They pointed that the observed significant correlation between OXL and methanesulfonate $\left(\mathrm{MS}^{-}\right)$in this region indicates that at least a fraction of OXL originates from marine sources. Such sources could be partly attributed to secondary formation from marine biogenic hydrocarbons (e.g. isoprene) (Liakakou et al., 2007), or photo-oxidation of biogenic fatty acids and longer chain acids (Legrand et al., 2007). In summertime, Finokalia is also influenced by biomass burning (Koulouri et al., 2008; Sciare et al., 2008), known to emit OXL and its precursors in the atmosphere. Figure 5a shows that $\mathrm{S} 3$ and S4 simulate more realistically the observed OXL concentrations (slope $=0.9 \pm 0.2, r^{2}=0.6$ ), compared to the base simulation (S1) (slope $\left.=0.7 \pm 0.2, r^{2}=0.5\right)$.

Amsterdam Island, located in the Southern Indian Ocean, is representative of pristine marine conditions, especially during summer when low wind speeds are prevailing (Sciare et al., 2009). OXL presents its maximum $\left(\sim 17 \pm 14 \mathrm{ng} \mathrm{m}^{-3}\right.$ in September; Fig. 5b) during early spring and minimum $\left(\sim 7 \pm 1 \mathrm{ng} \mathrm{m}^{-3}\right.$ in April; Fig. 5b) during early autumn (J. Sciare, unpublished data) in 2005 . Sciare et al. (2009) observed that both non-MS ${ }^{-}$water soluble organic carbon (WSOC) and $\mathrm{MS}^{-}$increase during summer, 


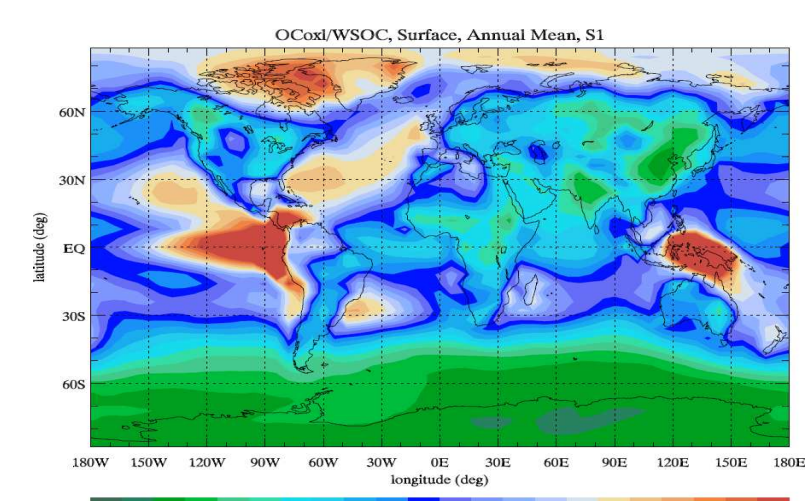

a)

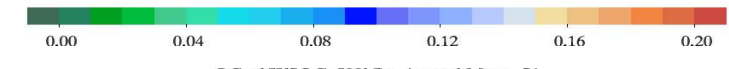

OCoxl/WSOC, 500hPa, Annual Mean, S1
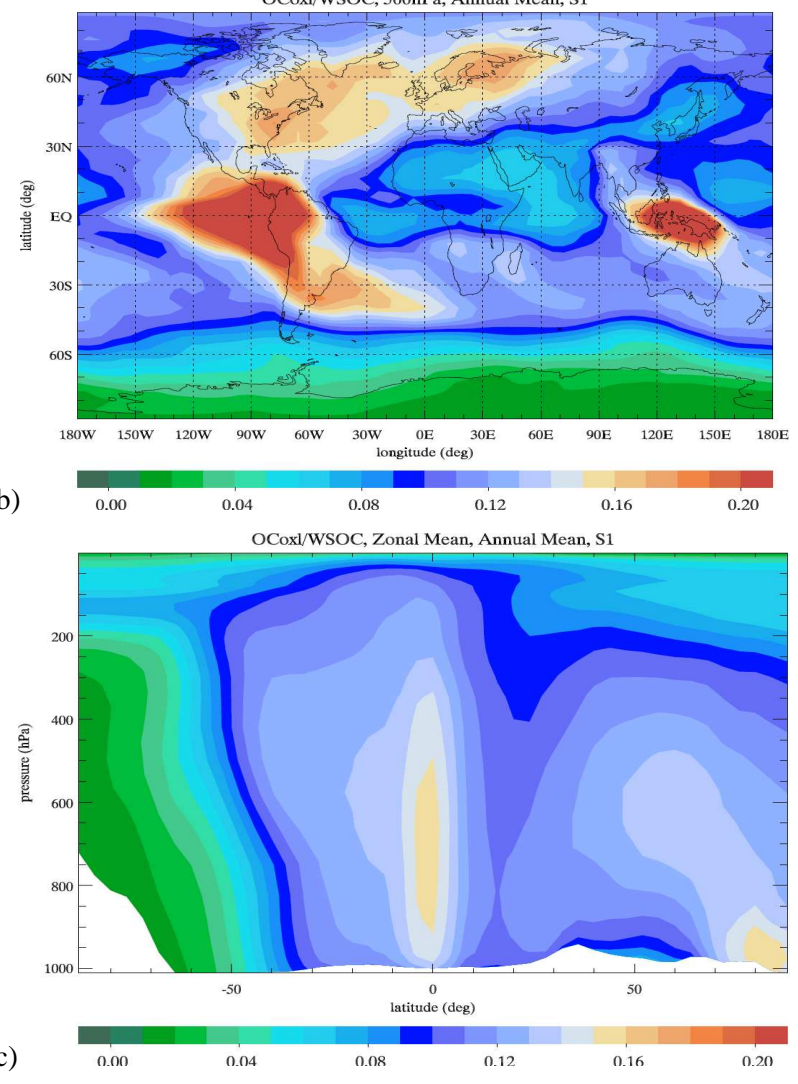

Fig. 4. Annual mean carbon mass ratios of oxalate, OCoxl, to total water soluble organic carbon, WSOC, in the model for S1 Simulation (a) surface, (b) $500 \mathrm{hPa}$, and (c) Zonal mean.

which would suggest a similar (secondary) production mechanism for WSOC and $\mathrm{MS}^{-}$that can be linked to the seasonality in marine productivity. TM4-ECPL (S1) predicts reasonably well the OXL observations at Amsterdam Island in both winter and summer periods (slope $=0.9 \pm 0.2$, $\left.r^{2}=0.5\right)$. During wintertime, fossil fuel emitted mainly from South Africa and biomass burning originating from the whole Austral Africa and Madagascar influence Amsterdam Island by long range transport (LRT), that is, how- ever, weak. Simulation S2 accounting for potentially primary combustion sources of OXL, shows that transport of such emissions (e.g. from Africa) and additional OXL formation in aerosol water (S3) does not significantly enhance OXL abundance, (slope $\left.=0.9 \pm 0.2, r^{2}=0.6\right)$. In case of direct marine GLY emissions ( $\mathrm{S} 4)\left(\right.$ slope $=1.3 \pm 0.6, r^{2}=0.2$ ), the calculated OXL concentrations are enhanced, especially during summer.

The Mace Head atmospheric research station (Jennings et al., 1997) is located on the west coast of Ireland, about $86 \mathrm{~km}$ westward of Galway City. The station is westerly exposed to the North Atlantic Ocean, with the Atlantic shipping routes located more than $150 \mathrm{~km}$ to the west of the station. The OXL observations depicted in Fig. 5c were performed from May 1998 to September 1999 (Kleefeld et al., 2002). From April to September marine air masses influenced the station, whereas from September to October pollution from continental Europe and UK was received. OXL (Fig. 5c) shows elevated concentrations from May to September and a decrease during winter (November-December). The model (S1) reasonably simulates the observations (slope $=0.4 \pm 0.1, r^{2}=$ $0.5)$ as reported by Kleefeld et al. (2002). However, primary OXL sources (S2) and OXL formation in aerosol water (S3) do not enhance significantly the model OXL concentrations. On the contrary, adoption of an additional source of GLY in the marine environment (S4) improves OXL simulations (slope $=0.6 \pm 0.1, r^{2}=0.6$ ), especially during the warm season (April to September).

Aveiro is a rural background station located in an area characterized by maritime pine, eucalyptus forests and small-scale agricultural fields used to grow maize in spring and summer, in Portugal (Pio et al., 2007). The maximum OXL monthly mean concentrations are observed in late summer $\left(\sim 429 \pm 200 \mathrm{ng} \mathrm{m}^{-3}\right.$ in August; Fig. 5d) and the minimum in winter $\left(\sim 160 \pm 43 \mathrm{ng} \mathrm{m}^{-3}\right.$ in December; Fig. 5d) (Legrand et al., 2007). The observations show a bi-modal seasonality with a secondary maximum in early spring that is not captured by the model. TM4-ECPL significantly under predicts the OXL observations year around. This could be attributed to high removal by precipitation in the model, shortening the atmospheric lifetime of OXL, or more likely to missing or not accurately distributed primary and secondary sources of OXL in the model (as discussed in Sect. 4). Figure 5d shows that S3 and S4 simulate more realistically the observed OXL concentrations (slope $=0.5 \pm 0.1, r^{2}=0.5$ ), compare to the base simulation (S1) and when biomass burning emissions of OXL are taken into account $(\mathrm{S} 2)\left(\right.$ slope $\left.=0.4 \pm 0.1, r^{2}=0.5\right)$.

Azores sampling station is representative of the background marine atmosphere over the mid-north Atlantic Ocean, influenced by LRT from North America, Europe and Africa and from local agricultural activities (Pio et al., 2007). Maximum OXL concentrations are observed during summertime $\left(\sim 100 \pm 16 \mathrm{ng} \mathrm{m}^{-3}\right.$ in June; Fig. 5e) and minimum during early spring $\left(\sim 15 \pm 15 \mathrm{ng} \mathrm{m}^{-3}\right.$ in March). Legrand et 
(a)

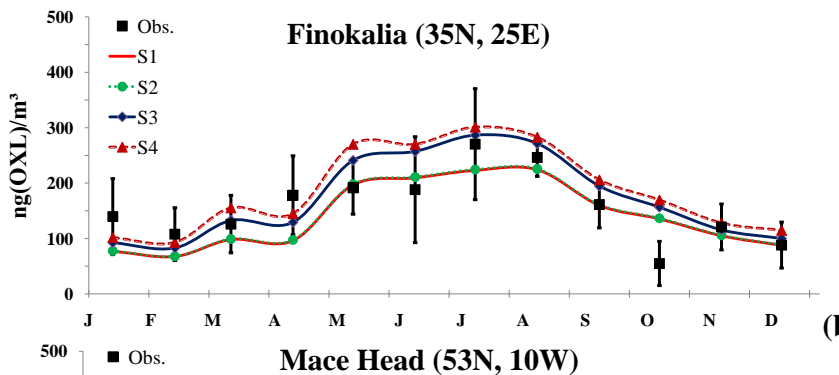

(c)

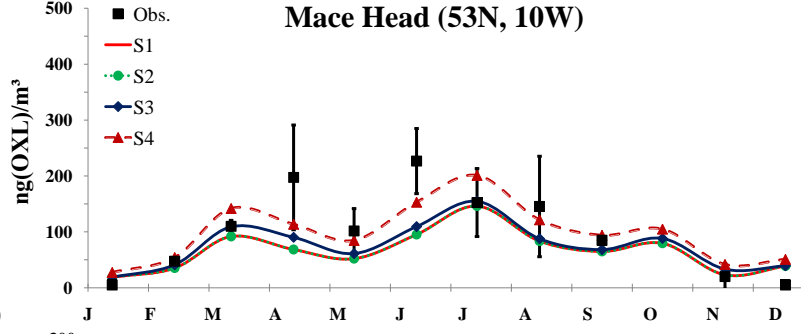

(e)

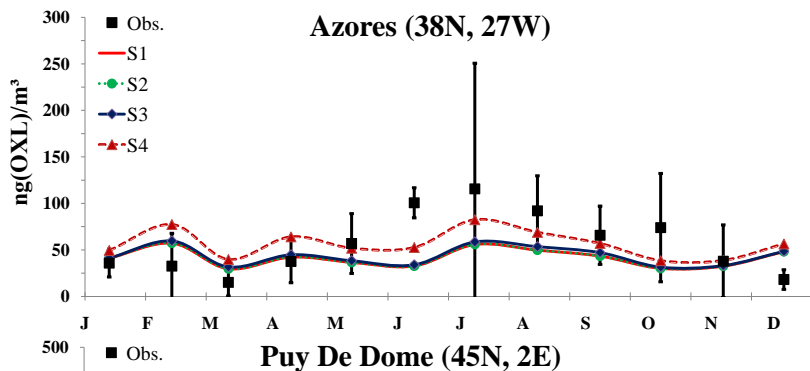

(g)

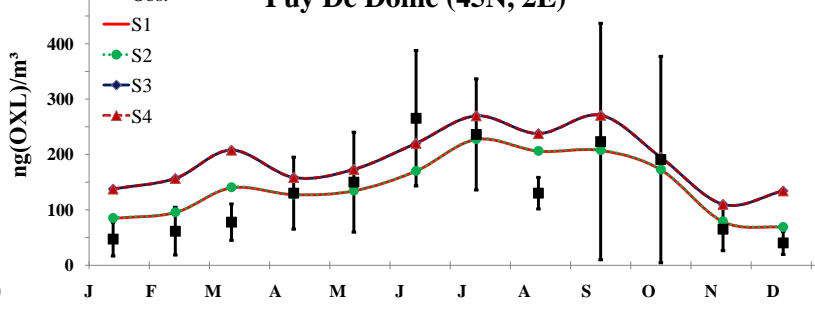

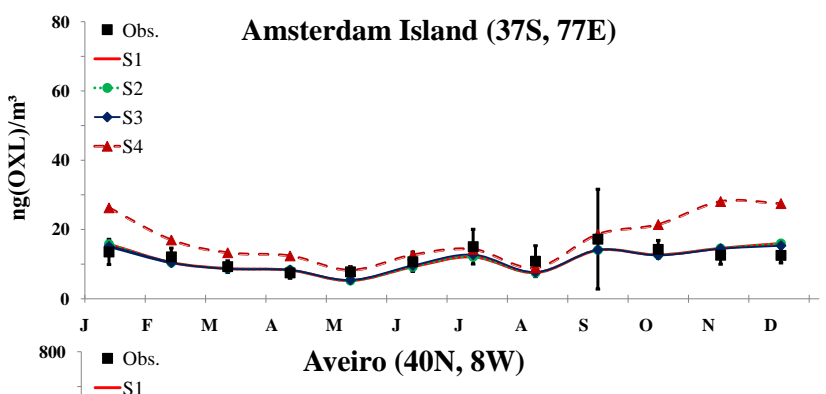

b)

(d)
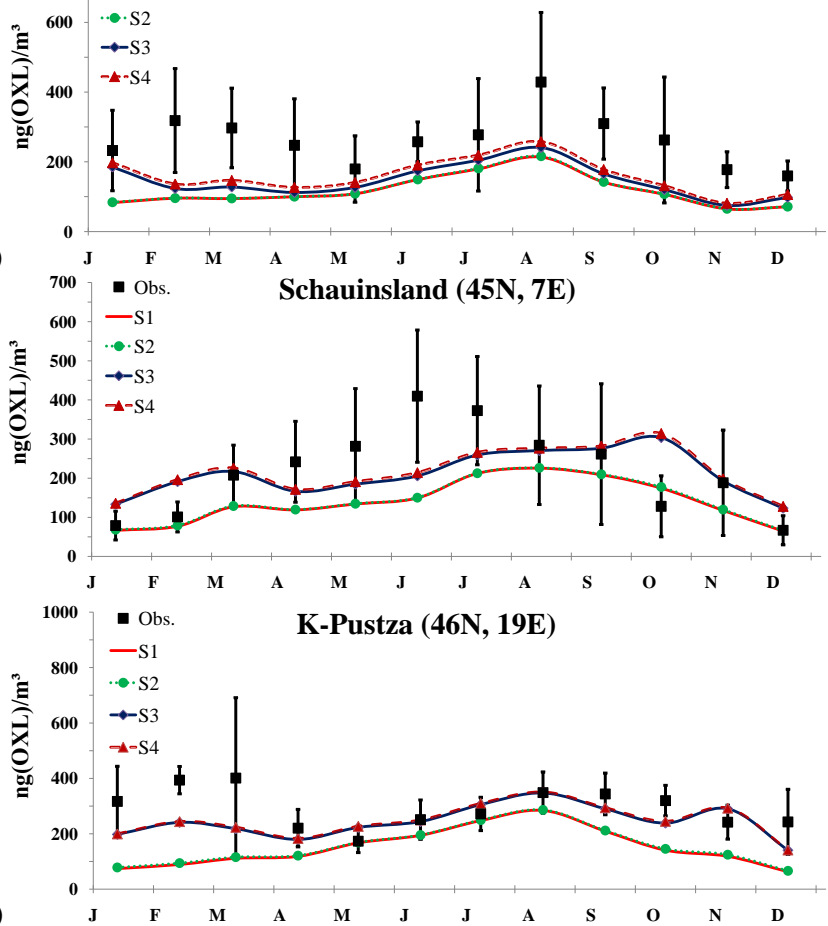

Fig. 5. Comparison of OXL observations black squares (a) in $\mathrm{ng} \mathrm{m}^{-3}$ with model results from simulations $\mathrm{S} 1$ light-red solid line (-),

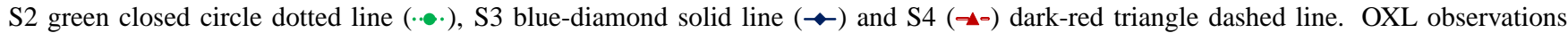
are taken from the Finokalia environmental monitoring station in Eastern Mediterranean (Koulouri et al., 2008; N. Mihalopoulos, personal communication, 2011) for the year 2005, Amsterdam Island in the Southern Indian Ocean (J. Sciare, personal communication, 2011) for the year 2005 and other locations in Europe (CARBOSOL sites from Legrand et al., 2007 and Simpson et al., 2007 for monthly mean measurements for period September 2002-September 2004, Mace Head Atmospheric Research Station on the west coast of Ireland from Kleefeld et al., 2002 for monthly mean measurements for period September 1998-September 1999).

al. (2007) suggested that LRT to Azores enhances organic diacid concentrations. In addition to the transported precursors for the in-cloud formation of OXL, local sources could also play a significant role in OXL abundance. Legrand et al. (2007) found that aerosols in Azores consist of unsaturated fatty acids that are commonly present in phytoplankton, particularly during summer, and have been suggested as OXL precursors (Oliveira et al., 2007). TM4-ECPL (S1-S3) is able to capture the mean levels of OXL with a yearly average OXL concentration of about $57 \pm 37 \mathrm{ng} \mathrm{m}^{-3}$, but cannot simulate the late spring/early summer high OXL observations (no correlation). Adoption of an additional source of
GLY in the marine environment (S4) slightly improves OXL simulations during summer at Azores.

The Schauinsland sampling site is a rural background station situated on a mountain ridge (1205 ma.s.l.) in the Black Forest (southwestern Germany). The site is surrounded by forests and agricultural fields, and during summer is influenced by LRT polluted air masses from the city of Freiburg in the Rhine valley (Legrand et al., 2007). The maximum OXL concentrations are observed in summer $\left(\sim 410 \pm 169 \mathrm{ng} \mathrm{m}^{-3}\right.$ in June; Fig. $\left.5 \mathrm{f}\right)$ and the minimum in winter $\left(\sim 67 \pm 37 \mathrm{ng} \mathrm{m}^{-3}\right.$ in December; Fig. 5f). Again, the model (S1 and S2) fails in 
reproducing the late spring/summer OXL observed high concentrations (slope $=0.3 \pm 0.1, r^{2}=0.4$ ), although significant improvement is achieved when accounting for OXL formation in aerosol water (S3) (slope $\left.=0.2 \pm 0.1, r^{2}=0.1\right)$. OXL formation during OA ageing (Eliason et al., 2003) might be a candidate to fill in the gap between model results and observations.

The Puy de Dome site, located on the top of the Puy de Dome mountain (1450 ma.s.l.) in central France, is a continental background sampling station, influenced by intensive agriculture and forest management activities, while in winter it is often under free tropospheric conditions (Legrand et al., 2007). The maximum OXL concentrations are observed during early summer $\left(\sim 265 \pm 122 \mathrm{ng} \mathrm{m}^{-3}\right.$ in June; Fig. $5 \mathrm{~g})$ and the minimum during winter $\left(\sim 41 \pm 21 \mathrm{ng} \mathrm{m}^{-3}\right.$ in December; Fig. 5g). The model ( $\mathrm{S} 1)$ simulates resonably the seasonality of OXL concentrations and the observed values ( slope $=0.6 \pm 0.1, r^{2}=0.7$ ). OXL emissions taken into account by the model (S2) do not seem to considerably enhance the calculated OXL concentrations, although significant changes are computed in S3 that accounts for the additional OXL production in the aerosol water (slope $=0.5 \pm 0.1, r^{2}=0.6$ ).

K-Puszta, a characteristic rural background station, is located in the middle of the Hungarian Plain, surrounded by forests, $60 \mathrm{~km}$ southeast from Budapest (Legrand et al., 2007). The maximum concentrations (Fig. 5h) are observed in early spring ( $\sim 401 \pm 290 \mathrm{ng} \mathrm{m}^{-3}$ in March) and the minimum in late spring $\left(\sim 173 \pm 41 \mathrm{ng} \mathrm{m}^{-3}\right.$ in May). Legrand et al. (2007) found that the K-Puszta region is highly influenced by vehicular emissions that represent a plausible source of oxalic acid, either primary or secondary. Vehicular emissions such as toluene and ethene, which are known OXL precursors, enhance its secondary formation. The model (S1, S2) significantly underpredicts the observed OXL concentrations during winter, indicating missing potential OXL sources (primary and secondary) or an overestimate of OXL removal by the model. On the contrary, during summer (May to July), high photochemical activity and enhanced precursor emissions result in more efficient OXL formation in the aqueous phase, and OXL concentrations calculated by TM4-ECPL are closer to observations. Again, OXL production in the aerosol water (S3) shows enhanced levels of OXL, closer to observations.

Further comparison of TM4-ECPL model results with observations from these stations is shown in Fig. S4 (Supplement) for OXL, OC, water soluble organic carbon (WSOC), $\mathrm{SO}_{4}^{2-}$ and the carbon mass ratios of OXL/WSOC, OXL/OC and $\mathrm{OXL} / \mathrm{SO}_{4}^{2-}$ (C to $\mathrm{S}$ mass ratio). This comparison indicates that TM4-ECPL is satisfactorily capturing the main observed patterns of these chemical variables.

In Fig. 6, OXL observations reported in literature are compared with monthly mean predictions for simulation S1. OXL measurements around the world are sparse (Fig. 6a).
The observations used in the present study and summarized in Table S3 (Supplement) show large variability both in the sampling duration (from a few minutes to several days) and in the timing of the sampling (daytime or nighttime). He and Kawamura (2010) have shown that nighttime observations of oxalic acid over polluted areas are about 1.3 times higher than the daytime ones. However, most of the data used for Fig. 6 concern relative long samplings, over several days, and have therefore trapped both daytime and nighttime levels of OXL. Comparison of the model results with available observations is nevertheless valuable to increase confidence in simulations and evaluate associated uncertainties (Fig. 6b). This is achieved by comparing monthly averaged model output for simulation S1 with the mean concentrations reported for the specific month at each location. Due to the relatively low resolution of the global model, the high spatial variability of urban emissions is not resolved by TM4-ECPL, thus classification of the stations as urban, rural and marine can facilitate data interpretation. Comparisons are focusing on locations representative of the regional background. Urban core observations, shown only for completeness, indicate a large underestimate by the model and have to be viewed with caution. ANOVA applied on the data depicted in Fig. 6b, shows that the model successfully represents the observations. Figure $6 \mathrm{~b}$ shows that the model simulates more realistically the marine (slope $=1.13 \pm 0.17, r^{2}=0.46$, $N=50, a=0.05, F=43, p$-value $\left.=3.85 \times 10^{-8}\right)$, and rural (marine and rural together: slope $=1.16 \pm 0.14, r^{2}=0.36$, $N=114 ; a=0.05, F=66, p$-value $\left.=7.48 \times 10^{-13}\right)$ observations, rather than the urban ones (no correlation). The statistical analysis of Figs. 5 and 6 (summarized in Table S4; Supplement) indicates that the model tends to underestimate significantly the importance of anthropogenic contribution to OXL atmospheric levels. Earlier publications report observations of fairly high oxalic acid concentrations up to $1370 \mathrm{ng} \mathrm{m}^{-3}$ in summer and $1440 \mathrm{ng} \mathrm{m}^{-3}$ in winter were also reported (14 cities of China; Ho et al., 2007), where the main sources in these areas are anthropogenic emissions of aerosols and their precursors of anthropogenic origin, followed by photochemical oxidation. Further, Kawamura et al. (unpublished data, 2007) measured oxalic acid concentrations up to $4 \mu \mathrm{g} \mathrm{m}^{-3}$ in the aerosols collected at Mt. Tai, North China Plain, in early summer, attributed to the biomass burning of agriculture wastes (wheat straw) after the harvesting. High concentrations of oxalic acid $\left(0.4-4.5 \mu \mathrm{g} \mathrm{m}^{-3}\right)$ have also been observed in New Delhi, India (Miyazaki et al., 2009). Overall, as can be seen by the slopes of the correlations, the model tends to underestimate OXL observations, which indicates that the model either misses OXL sources (primary and secondary) or possibly overestimates OXL sinks. 

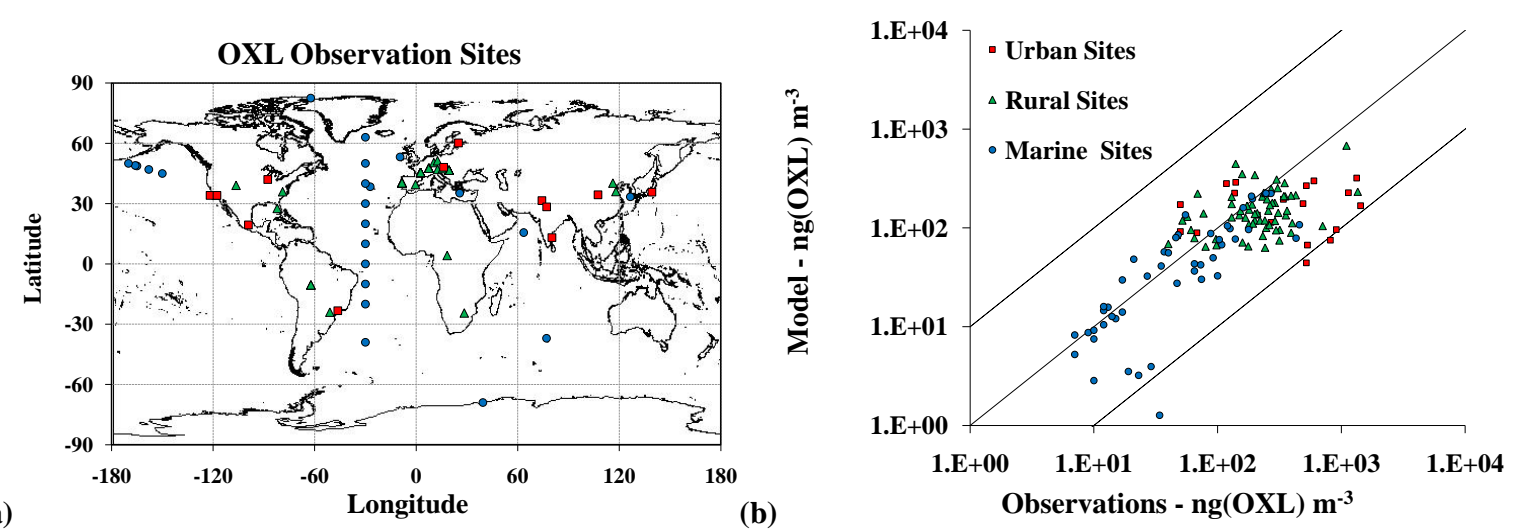

Fig. 6. (a) Location of stations with OXL observations taken into account for the model validations. (b) Comparison of OXL measurements with TM4-ECPL results for S1 (base simulation). Red squares represent urban sites, green triangles represent rural sites and blue circles marine sites. The solid line shows the 1:1 relationship between model results and measurements and the dotted line shows the 1:10 and 10:1 relationship. Measurements are taken from: Baboukas et al. (2000); Biswas et al. (2008); Crahan et al. (2004); Falkovich et al. (2005); Fosco and Schmeling (2006); Graham et al. (2002); Grosjean (1988); He and Kawamura (2010); Kawamura et al. (1985, 1996, 2005); Kawamura and Ikushima (1993); Kleefeld et al. (2002); Kundu et al. (2010b); Legrand et al. (2007); Lewandowski et al. (2007); Limbeck and Puxbaum (1999); Limbeck et al. (2005); Martinelango et al. (2007); N. Mihalopoulos (personal communication, 2011); Miyazaki et al. (2009, 2010); Müller et al. (2005); Neususs et al. (2002); Norton et al. (1983); Pavuluri et al. (2010); Plewka et al. (2006); Puxbaum et al. (2000); Ruellan et al. (1999); Saarnio et al. (2010); J. Sciare (personal communication, 2011); Sempere and Kawamura (1994); Souza et al. (1999); Stone et al. (2010); Talbot et al. (1988); Topping et al. (2004); Viana et al. (2008); Wang et al. (2010) (see details in Table S3 in Supplement).

\section{Conclusions}

The global 3-dimensional chemistry/transport model TM4ECPL has been adapted to simulate the temporal and spatial OXL distribution. The global OXL net chemical source has been estimated to be between $13 \mathrm{Tg} \mathrm{yr}^{-1}$ and $24 \mathrm{Tg} \mathrm{yr}^{-1}$. Primary biomass burning OXL sources of about $0.1 \mathrm{Tg} \mathrm{yr}^{-1}$ have not enhanced much the calculated OXL concentrations, which indicates that further investigations are needed on OXL emissions from combustion processes. The potential OXL formation into aerosol water is predicted to enhance its chemical formation up to $\sim 2 \mathrm{Tg} \mathrm{yr}^{-1}$ and is a strong candidate to explain the observed OXL concentrations at NH locations. A potential GLY source over oceans of $20 \mathrm{Tg} \mathrm{yr}^{-1}$ is calculated to significantly contribute to OXL net chemical production (by $\sim 1.5 \mathrm{Tg} \mathrm{yr}^{-1}$ ); although further study is required to understand the atmospheric levels and distribution of GLY over marine areas.

Isoprene is calculated to be the most important OXL precursor $(\sim 70 \%)$. More than $60 \%$ of OXL is removed from the atmosphere via wet deposition. The global tropospheric burden of OXL is calculated to be about $0.2-0.3 \mathrm{Tg}$. The computed OXL global mean turnover time against deposition is about 5 days. The composition of cloud droplets and especially cloud water ionic strength is shown to be a critical factor of uncertainty in the calculations of OXL atmospheric chemical production, due to its impact on the effective Henry's law constant values and deserves further investigations.
The present global 3-dimensional modeling study underlines the significant contribution of the atmospheric aqueousphase processes to the organic aerosol mass in the atmosphere. According to TM4-ECPL model calculations, OXL increases the calculated global tropospheric burden of water soluble organic carbon by 5-9\% when expressed in carbon mass. Comparison of calculated OXL concentrations with observations shows that TM4-ECPL underestimates OXL measurements, especially during winter. This indicates that potentially other secondary or primary sources or weaker sinks need to be considered to better describe the global tropospheric OXL abundance.

Further investigations are needed to improve our knowledge on such processes and in particular to properly account for gas-to-aqueous phase organic compounds transfer. Aqueous-phase oxidation of longer carboxylic acids and marine unsaturated fatty acids to shorter diacids and carboxylic acid formation during OA photo-ageing processes, which are neglected in the present study, could lead to a further enhancement of OXL and OA in the troposphere.

\section{Supplementary material related to this article is available online at: http://www.atmos-chem-phys.net/11/5761/2011/ acp-11-5761-2011-supplement.pdf.}


Acknowledgements. This work was supported by the EUCAARI (European Integrated Project on Aerosol Cloud Climate Air Quality Interactions), the PEGASOS (Pan-European Gas-AeroSOls-climate interaction Study) and its presentation has been facilitated by the ACCENT (Atmospheric Composition Change - The European Network of Excellence). S. M. acknowledges support by a PENED 03ED373 grant co-financed by EU-European Social Fund (75\%) and the Greek Ministry of Development - GSRT (25\%) at early stages of this work. Measurements performed at Amsterdam Island were supported by the French Polar Institute (IPEV) within the AEROTRACE program. We would like to thank D. Simpson, C. A. Pio and CARBOSOL (Present and retrospective state of organic versus inorganic aerosol over Europe: implication for climate) consortium for data availability. We thank F. J. Dentener and M. Krol for helpful recommendations concerning model development, E. Gerasopoulos for statistical analysis, R. Volkamer for useful discussions and B. Ervens for constructive comments on the aqueous phase chemical scheme.

Edited by: E. Swietlicki

\section{References}

Altieri, K. E., Carlton, A. G., Lim, H. J., Turpin, B. J., and Seitzinger, S.: Evidence for oligomer formation in clouds: Reactions of isoprene oxidation products, Environ. Sci. Technol., 40, 4956-4960, 2006.

Altieri, K. E., Seitzinger, S. P., and Carlton, A. G.: Oligomers formed through in-cloud methylglyoxal reactions: Chemical composition, properties, and mechanisms investigated by ultrahigh resolution FT-ICR mass spectrometry, Atmos. Environ., 42, 1476-1490, 2008.

Altieri, K. E., Turpin, B. J., and Seitzinger, S. P.: Composition of dissolved organic nitrogen in continental precipitation investigated by ultra-high resolution FT-ICR mass spectrometry, Environ. Sci. Technol., 43, 6950-6955, 2009.

Aiken, A. C., Decarlo, P. F., Kroll, J. H., Worsnop, D. R., Huffman, J. A., Docherty, K. S., Ulbrich, I. M., Mohr, C., Kimmel, J. R., Sueper, D., Sun, Y., Zhang, Q., Trimborn, A., Northway, M., Ziemann, P. J., Canagaratna, M. R., Onasch, T. B., Alfarra, M. R., Prevot, A. S. H., Dommen, J., Duplissy, J., Metzger, A., Baltensperger, U., and Jimenez, J. L.: O/C and OM/OC ratios of primary, secondary, and ambient organic aerosols with high resolution time-of-flight aerosol mass spectrometry, Environ. Sci. Technol., 42, 4478-4485, doi:10.1021/es703009q, 2008.

Baboukas, E. D., Kanakidou, M., and Mihalopoulos, N.: Carboxylic acids in gas and particulate phase above the Atlantic Ocean, J. Geophys. Res., 105, 14459-14471, 2000.

Barth, M. C., Sillman, S., Hudman, R., Jacobson, M. Z., Kim, C.H., Monod, A., and Liang, J.: Summary of the cloud chemistry modeling intercomparison: Photochemical box model simulation, J. Geophys. Res., 108, 4214, doi:10.1029/2002JD002673, 2003.

Biswas, K. F., Ghauri, B. M., and Husain, L.: Gaseous and aerosol pollutants during fog and clear episodes in South Asian urban atmosphere, Atmos. Environ., 42, 7775-7785, 2008.

Blando, J. D. and Turpin, B. J.: Secondary organic aerosol formation in cloud and fog droplets: a literature evaluation of plausi- bility, Atmos. Environ., 34, 1623-1632, 2000.

Buxton, G. V., Malone, T. N., and Salmon, G. A.: Oxidation of glyoxal initiated by $\mathrm{OH}$ in oxygenated aqueous solution, J. Chem. Soc., Faraday Trans., 93, 2889-2891, 1997.

Carlton, A. G., Turpin, B. J., Lim, H.-J., Altieri, K. E., and Seitzinger, S.: Link between isoprene and secondary organic aerosol (SOA): Pyruvic acid oxidation yields low volatility organic acids in clouds, Geophys. Res. Lett., 33, L06822, doi:10.1029/2005GL025374, 2006.

Carlton, A. G., Turpin, B. J., Altieri, K. E., Seitzinger, S., Reff, A., Lim, H.-J., and Ervens, B.: Atmospheric oxalic acid and SOA production from glyoxal: Results of aqueous photooxidation experiments, Atmos. Environ., 41, 7588-7602, 2007.

Crahan, K. K., Hegg, D., Covert, D. S., and Jonsson H.: An exploration of aqueous oxalic acid production in the coastal marine atmosphere, Atmos. Environ. 38, 3757-3764, 2004.

De Gouw, J. A., Brock, C. A., Atlas, E. L., Bates, T. S., Fehsenfeld, F. C., Goldan, P. D., Holloway, J. S., Kuster, W. C., Lerner, B. M., Matthew, B. M., Middlebrook, A. M., Onasch, T. B., Peltier, R. E., Quinn, P. K., Senff, C. J., Stohl, A., Sullivan, A. P., Trainer, M., Warneke, C., Weber, R. J., and Williams, E. J.: Sources of particulate matter in the northeastern United States in summer: 1. Direct emissions and secondary formation of organic matter in urban 30 plumes, J. Geophys. Res., 113, D08301, doi:10.1029/2007JD009243, 2008.

Dentener, F., Kinne, S., Bond, T., Boucher, O., Cofala, J., Generoso, S., Ginoux, P., Gong, S., Hoelzemann, J. J., Ito, A., Marelli, L., Penner, J. E., Putaud, J.-P., Textor, C., Schulz, M., van der Werf, G. R., and Wilson, J.: Emissions of primary aerosol and precursor gases in the years 2000 and 1750 prescribed data-sets for AeroCom, Atmos. Chem. Phys., 6, 4321-4344, doi:10.5194/acp6-4321-2006, 2006.

Eliason, T. L., Aloisio, S., Donaldson, D.J., Cziczo, D.J., and Vaida V.: Processing of unsaturated organic acid films and aerosols by ozone, Atmos. Environ., 37, 2207-2219, 2003.

Ervens, B. and Volkamer, R.: Glyoxal processing outside clouds: towards a kinetic modeling framework of secondary organic aerosol formation in aqueous particles, Atmos. Chem. Phys., 10, 8219-8244, doi:10.5194/acp-10-8219-2010, 2010.

Ervens, B., George, C., Williams, J. E., Buxton, G. V., Salmon, G.A., Bydder, M., Wilkinson, F., Dentener, F., Mirabel, P., Wolke, R., and Herrmann, H.: CAPRAM2.4 (MODAC mechanism): An extended and condensed tropospheric aqueous phase mechanism and its application, J. Geophys. Res., 108(D14), 4426, doi:10.1029/2002JD002202, 2003.

Ervens, B., Feingold, G., Frost, G. J., Kreidenweis S. M.: A modeling study of aqueous production of dicarboxylic acids: 1 . Chemical pathways and speciated organic mass production, J. Geophys. Res., 109, D15205, doi:10.1029/2003JD004387, 2004.

Ervens, B., Carlton, A. G., Turpin, B. J., Altieri, K. E., Kreidenweis, S. M., and Feingold, G.: Secondary organic aerosol yields from cloud-processing of isoprene oxidation products, Geophys. Res. Letters, 35, L02816, doi:10.1029/2007GL031828, 2008.

Falkovich, A. H., Graber, E. R., Schkolnik, G., Rudich, Y., Maenhaut, W., and Artaxo, P.: Low molecular weight organic acids in aerosol particles from Rondônia, Brazil, during the biomassburning, transition and wet periods, Atmos. Chem. Phys., 5, 781797, doi:10.5194/acp-5-781-2005, 2005.

Fosco, T. and Schmeling, M.: Aerosol ion concentration 
dependence on atmospheric conditions in Chicago, Atmos. Environ. 40, 6638-6649, 2006.

Fountoukis, C. and Nenes, A.: ISORROPIA II: a computationally efficient thermodynamic equilibrium model for $\mathrm{K}^{+}-$ $\mathrm{Ca}^{2+}-\mathrm{Mg}^{2+}-\mathrm{NH}_{4}^{+}-\mathrm{Na}^{+}-\mathrm{SO}_{4}^{2-}-\mathrm{NO}_{3}^{-}-\mathrm{Cl}^{-}-\mathrm{H}_{2} \mathrm{O}$ aerosols, Atmos. Chem. Phys., 7, 4639-4659, doi:10.5194/acp-7-4639-2007, 2007.

Fu, T.-M., Jacob, D. J., Wittrock, F., Burrows, J. P., Vrekoussis, M., and Henze, D.: Global budgets of atmospheric glyoxal and methylglyoxal, and implications for formation of secondary organic aerosols, J. Geophys. Res., 113, D15303, doi:10.1029/2007JD009505, 2008.

Fuzzi, S.: Clouds in the troposphere, Contribution to IGAC Newsletter, 23, available at: http://igac.jisao.washington.edu/ newsletter/igac23/Apr_2001_IGAC_23.pdf, 2001.

Galloway, M. M., Chhabra, P. S., Chan, A. W. H., Surratt, J. D., Flagan, R. C., Seinfeld, J. H., and Keutsch, F. N.: Glyoxal uptake on ammonium sulphate seed aerosol: reaction products and reversibility of uptake under dark and irradiated conditions, Atmos. Chem. Phys., 9, 3331-3345, doi:10.5194/acp-9-3331-2009, 2009.

Garcia-Alonso, S., Perez-Pastor, R., and Sevillano-Castano, M. L.: Determination of glyoxal and methylglyoxal in atmospheric particulate matter by 2,4-dinitrophenylhydrazine derivatisation, Toxicol. Environ. Chem., 88, 445-452, doi:10.1080/02772240600796837, 2006.

Granier, C., Guenther, A., Lamarque, J., Mieville, A., Müller, J., Olivier, J., Orlando, J., Peters, J., Petron, G., Tyndall, G., and Wallens, S.: POET, a database of surface emissions of ozone precursors, available at: http://www.aero.jussieu.fr/projet/ ACCENT/POET.php, 2005.

Gelencser, A. and Varga. Z.: Evaluation of the atmospheric significance of multiphase reactions in atmospheric secondary organic aerosol formation, Atmos. Chem. Phys., 5, 2823-2831, doi:10.5194/acp-5-2823-2005, 2005.

Graham, B., Mayol-Bracero, O.L., Guyon, P., Roberts, G.C., Decesari, S., Facchini, M.C., Artaxo, P., Maenhaut, W., Koll, P., Andreae, M.O.: Water-soluble organic compounds in biomass burning aerosols over Amazonia - 1. Characterization by NMR and GC-MS, J. Geophys. Res., 107, 8047-8063, doi:10.1029/2001JD000336, 2002.

Grosjean, D.: Aldehydes, carboxylic acids and inorganic nitrate during NSMCS, Atmos. Environ., 22, 1637-1648, 1988.

Guenther, A., Hewitt, C. N., Erickson, D., Fall, R., Geron, C., Graedel, T. E., Harley, P., Klinger, L., Lerdau, M., McKay, W. A., Pierce, T., Scholes, B., Steinbrecher, R., Tallamraju, R., Taylor, J., Zimmerman, P.: A global model of natural volatile organic compound emissions, J. Geophys. Res., 100, 8873-8892, 1995.

Hallquist, M., Wenger, J. C., Baltensperger, U., Rudich, Y., Simpson, D., Claeys, M., Dommen, J., Donahue, N. M., George, C., Goldstein, A. H., Hamilton, J. F., Herrmann, H., Hoffmann, T., Iinuma, Y., Jang, M., Jenkin, M. E., Jimenez, J. L., Kiendler-Scharr, A., Maenhaut, W., McFiggans, G., Mentel, Th. F., Monod, A., Prévôt, A. S. H., Seinfeld, J. H., Surratt, J. D., Szmigielski, R., and Wildt, J.: The formation, properties and impact of secondary organic aerosol: current and emerging issues, Atmos. Chem. Phys., 9, 5155-5236, doi:10.5194/acp-95155-2009, 2009.

He, N. and Kawamura, K.: Distributions and diurnal changes of low molecular weight organic acids and $\alpha$-dicarbonyls in suburban aerosols collected at Mangshan, North China, Geochem. J., 44, e17-e22, 2010.

Heald, C. L., Jacob, D. J., Park, R. J., Russell, L. M., Huebert, B. J., Seinfeld, J. H., Liao, H., and Weber, R. J.: A large organic aerosol source in the free troposphere missing from current models, J. Geophys. Res. 32, L18809, doi:10.1029/2005GL023831, 2005.

Heald, C. L., Jacob, D. J., Turquety, S., Hudman, R. C., Weber, R. J., Sullivan, A. P., Peltier, R. E., Atlas, E. L., de Gouw, J. A., Warneke, C., Holloway, J. S., Neuman, A., Flocke, F. M., and Seinfeld, J. H.: Concentrations and sources of organic carbon aerosols in the free troposphere over North America, J. Geophys. Res., 111, D23S47, doi:10.1029/2006JD007705, 2006.

Hecobian, A., Zhang, X., Zheng, M., Frank, N., Edgerton, E. S., and Weber, R. J.: Water-Soluble Organic Aerosol material and the light-absorption characteristics of aqueous extracts measured over the Southeastern United States, Atmos. Chem. Phys., 10, 5965-5977, doi:10.5194/acp-10-5965-2010, 2010.

Hennigan, C. J., Bergin, M. H., Dibb, J. E., Weber, R. J.: Enhanced secondary organic aerosol formation due to water uptake by fine particles, Geophys. Res. Lett., 35, L18801, doi:10.1029/2008GL035046, 2008.

Hennigan, C. J., Bergin, M. H., Russell, A. G., Nenes, A., and Weber, R. J.: Gas/particle partitioning of water-soluble organic aerosol in Atlanta, Atmos. Chem. Phys., 9, 3613-3628, doi:10.5194/acp-9-3613-2009, 2009.

Herrmann, H.: Kinetics of Aqueous Phase Reactions Relevant for Atmospheric Chemistry, Chem. Rev., 103, 4691-4716, doi:10.1021/cr020658q, 2003.

Herrmann, H., Ervens, B., Jacobi, H.-W., Wolke R., Nowacki P, and Zellner R.: CAPRAM2.3: A Chemical Aqueous Phase Radical Mechanism for Tropospheric Chemistry, J. Atmos. Chem., 36, 231-284, 2000.

Herrmann, H., Tilgner, A., Barzaghi, P., Majdik, Z., Gligorovski, S., Poulain, L. and Monod, A.: Towards a more detailed description of tropospheric aqueous phase organic chemistry: CAPRAM 3.0., Atmos. Environ., 39, 4351-4363, 2005.

Ho, K. F., Cao, J. J., Lee, S. C., Kawamura, K., Zhang, R J., Chow, J. C., and Watson, J. G.: Dicarboxylic acids, ketocarboxylic acids, and dicarbonyls in the urban atmosphere of China, J. Geophys. Res., 112, D22S27, doi:10.1029/2006JD008011, 2007.

Hoyle, C. R., Myhre, G., Berntsen, T. K., and Isaksen, I. S. A.: Anthropogenic influence on SOA and the resulting radiative forcing, Atmos. Chem. Phys., 9, 2715-2728, doi:10.5194/acp-9-27152009, 2009.

Huang, X. F. and Yu, J. Z.: Is vehicle exhaust a significant primary source of oxalic acid in ambient aerosols?, Geophys. Res. Lett., 34, L02808, doi:10.1029/2006GL028457, 2007.

Ip, H. S. S., Huang, X. H. H., and Yu, J. Z.: Effective Henry's law constants of glyoxal, glyoxylic acid, and glycolic acid, Geophys. Res. Lett., 36, L01802, doi:10.1029/2008GL036212, 2009.

Jathar, S. H., Farina, S. C., Robinson, A. L., and Adams, P. J.: The influence of semi-volatile and reactive primary emissions on the abundance and properties of global organic aerosol, Atmos. Chem. Phys. Discuss., 11, 5493-5540, doi:10.5194/acpd11-5493-2011, 2011.

Jennings, S. G., Geever, M., McGovern, F. M., Francis, J., Spain, T. G., and Donaghy, T.: Microphysical and physico-chemical 
characterization of atmospheric marine and continental aerosol at Mace Head, Atmos. Environ., 31, 2795-2808, 1997.

Jimenez, J. L., Canagratna, M. R., Donahue, N. M., Prevot, A. S. H., Zhang, Q., Kroll, J. H., DeCarlo, P. F., Allan, J. D., Coe, J., Ng, N. L., Aiken, A. C., Docherty, K. S., Ulbrich, I. M., Grieshop, A. P., Robinson, A. L., Duplissy, J., Smith, J. D., Wilson, K. R., Lanz, V. A., Hueglin, C., Sun. Y. L., Tian, J., Laaksone, A., Raatikainen, T., Rautianen, J., Vaattovaara, P, Ehn, M., Kulmala, M., Tomlinson, J. M., Collins, D. R., Cubison, M. J., Dunlea, E. J., Huffman, J. A., Onasch, T. B., Alfarra, M. R., Williams, P. I., Bower, K., Kondo, Y., Schneider, J., Drewnick, F., Borrmann, S., Weimer, S., Demerjian, K., Slacedo, D., Cottrell, L., Griffin, R., Takami, A., Miyoshi, T., Hatakeyama, S., Shimono, A., Sun, J. Y., Zhang, Y. M., Dzepina, K., Kimmel, J. R., Sueper, D., Middlebrook, A. M., Kolb, C. E., Baltensperger, U., and Worsnop, D. R.: Evolution of organic aerosols in the atmosphere, Science, 326, 1525-1529, doi:10.1126/science.1180353, 2009.

Jeuken, A., Veefking, J. P., Dentener, F., Metzger, S., and Robles Gonzalez, C.: Simulation of the aerosol oprtical depth over Europe for August 1997 and comparison with observations, J. Geophys. Res., 106, 28295-28311, 2001.

Kanakidou, M., Seinfeld, J. H., Pandis, S. N., Barnes, I., Dentener, F. J., Facchini, M. C., Van Dingenen, R., Ervens, B., Nenes, A., Nielsen, C. J., Swietlicki, E., Putaud, J. P., Balkanski, Y., Fuzzi, S., Horth, J., Moortgat, G. K., Winterhalter, R., Myhre, C. E. L., Tsigaridis, K., Vignati, E., Stephanou, E. G., and Wilson, J.: Organic aerosol and global climate modelling: a review, Atmos. Chem. Phys., 5, 1053-1123, doi:10.5194/acp-5-1053-2005, 2005.

Kawamura, K. and Ikushima, K.: Seasonal changes in the distribution of dicarboxylic acids in the urban atmosphere, Environ. Sci. Technol., 27, 2227-2235, 1993.

Kawamura, K. and Kaplan, I. R.: Motor exhaust emissions as a primary source for dicarboxylic acids in Los Angeles ambient air, Environ. Sci. Technol., 21, 105-110, 1987.

Kawamura, K. and Sakaguchi, F.: Molecular distributions of watersoluble dicarboxylic acids in marine aerosols over the Pacific Ocean including tropics, J. Geophys. Res., 104(D3), 3501-3509, 1999.

Kawamura, K. and Usukura, K.: Distributions of Low Molecular Weight Dicarboxylic Acids in the North Pacific Aerosol Samples, J. Oceanogr., 49, 271-283, 1993.

Kawamura, K., Ng, L.-L., and Kaplan, I. R.: Determination of Organic Acids (Cl-Cl0) in the Atmosphere, Motor Exhausts and Engine Oils, Environ. Sci. Technol., 19, 1082-1086, 1985.

Kawamura, K., Kasukabe, H., Yasui, O., and Barrie, L. A.: Production of dicarboxylic acids in the arctic atmosphere at polar sunrise, Geophys. Res. Lett., 22, 1253-1256, 1995a.

Kawamura, K., Kosaka, M., and Sempéré, R.: Distributions and seasonal changes of hydrocarbons in urban aerosols and rainwaters, Chikyukagaku (Geochemistry), 29, 1-15, 1995 b.

Kawamura, K., Kasukabe, H., and Barrie, L. A.: Source and reaction pathways of dicarboxylic acids, ketoacids and dicarbonyls in arctic aerosols: One year of observations, Atmos. Environ., 30, 1709-1722, 1996.

Kawamura, K., Kobayashi, M., Tsubonuma, N., Mochida, M., Watanabe, T., Lee, M.: Organic and inorganic compositions of marine aerosols from East Asia: Seasonal variations of watersoluble dicarboxylic acids, major ions, total carbon and nitro- gen, and stable $\mathrm{C}$ and $\mathrm{N}$ isotopic composition, Geochemical Investigations In Earth And Space Sciences: A Tribute To Isaac R. Kaplan, The Geochemical Society Special Publications, 9, ISBN-13: 978-0-444-51647-3, ISBN-10:0-444-51647-6, $243-$ 265, http://hdl.handle.net/2115/27999, 2004.

Kawamura, K., Imai, Y., and Barrie L. A.: Photochemical production and loss of organic acids in high Arctic aerosols during longrange transport and polar sunrise ozone depletion events, Atmos. Environ., 39, 599-614, 2005.

Kleefeld, S., Hofferb, A., Krivacsy, Z., and Jennings, S. G.: Importance of organic and black carbon in atmospheric aerosols at Mace Head, on the West Coast of Ireland (5319' N, 954' W), Atmos. Environ., 36, 4479-4490, 2002.

Koulouri, E., Saarikoski, S., Theodosi, C., Markaki, Z., Gerasopoulos, E., Kouvarakis, G., Makela, T., Hillamo, R., and Mihalopoulos, N.: Chemical composition and sources of fine and coarse aerosol particles in the Eastern Mediterranean, Atmos. Environ. 42, 6542-6550, 2008.

Kouvarakis, G., Vrekoussis, M., Mihalopoulos, N., Kourtidis, K., Rappenglueck, B., Gerasopoulos, E., and Zerefos, C.: Spatial and temporal variability of tropospheric ozone $\left(\mathrm{O}_{3}\right)$ in the boundary layer above the Aegean Sea (eastern Mediterranean), J. Geophys. Res., 107, 8137, doi:10.1029/2000JD000081, 2002.

Kraemer, S.: Iron oxide dissolution and solubility in the presence of siderophores, Aquat. Sci., 66, 3-18, doi:10.1007/s00027-0030690-5, 2004.

Kundu, S., Kawamura, K., Andreae, T. W., Hoffer, A., and Andreae, M. O.: Molecular distributions of dicarboxylic acids, ketocarboxylic acids and $\alpha$-dicarbonyls in biomass burning aerosols: implications for photochemical production and degradation in smoke layers, Atmos. Chem. Phys., 10, 2209-2225, doi:10.5194/acp-10-2209-2010, 2010a.

Kundu, S., Kawamura, K., Lee, M., Andreae, T. W., Hoffer, A., and Andreae, M. O.: Comparison of Amazonian biomass burning and East Asian marine aerosols: Bulk organics, diacids and related compounds, water-soluble inorganic ions, stable carbon and nitrogen isotope ratios, Low Temp. Sci., 68, 89-100, 2010b.

Landgraf, J. and Crutzen, P. J.: An efficient method for online calculation of photolysis and heating rates, J. Atmos. Sci., 55, 863878, 1998.

Legrand, M., Preunkert, S., Oliveira, T., Pio, C., Hammer, S., Gelencser, A., Kasper-Giebl, A., Laj, P.: Origin of C2-C5 dicarboxylic acids in the European atmosphere inferred from yearround aerosol study conducted at a west-east transect, J. Geophys. Res., 112, D23S07, doi:10.1029/2006JD008019, 2007.

Lelieveld J. and Crutzen, P.J.: The role of clouds in tropospheric photochemistry, J. Atmos. Chem., 12, 229-267, 1991.

Lelieveld, J., Crutzen, P. J., and Rodhe, H.: Zonal average cloud characteristics for global atmospheric chemistry modelling. Report CM-76, Department of Meteorology, University of Stockholm, Sweden, 1989.

Lelieveld, J., Peters, W., Dentener, F. J., and Krol, M. C.: Stability of tropospheric hydroxyl chemistry, J. Geophys. Res., 107, 4715, doi:10.1029/2002JD002272, 2002.

Lewandowski, M., Jaoui, M., Kleindienst, T. E., Offenberg, J. H., Edney, E. O.: Composition of $\mathrm{PM}_{2.5}$ during the summer of 2003 in Research Triangle Park, North Carolina, Atmos. Environ., 41, 4073-4083, 2007.

Liakakou, E., Vrekoussis, M., Bonsang, B. Donousis, Ch., 
Kanakidou, M., and Mihalopoulos N.: Isoprene above the Eastern Mediterranean: Seasonal variation and contribution to the oxidation capacity of the atmosphere, Atmos. Environ., 41, 10021010, doi:10.1016/j.atmosenv.2006.09.034, 2007.

Liggio, J., Li, S.M., and McLaren, R.: Reactive uptake of glyoxal by particulate matter, J. Geophys. Res., 110, D10304, doi:10.1029/2004JD005113, 2005a.

Liggio, J., Li, S. M., and McLaren, R.: Heterogeneous reactions of glyoxal on particulate matter identification of acetals and sulfate esters, Environ. Sci. Technol., 39, 1532-1541, 2005 b.

Liggio, J. and McLaren, R.: An optimized method for the determination of volatile and semi-volatile aldehydes and ketones in ambient particulate matter, Intern. J. Environ. Anal. Chem., 83, 819-835, 2003.

Lim, H. J., Carlton, A. G., and Turpin, B. J.: Isoprene forms secondary organic aerosol through cloud processing: Model simulations, Environ. Sci. Technol., 39, 4441-4446, 2005.

Lim, Y. B., Tan Y., Perri, M. J., Seitzinger, S. P., and Turpin, B.J.: Aqueous chemistry and its role in secondary organic aerosol (SOA) formation, Atmos. Chem. Phys., 10, 1052110539, doi:10.5194/acp-10-10521-2010, 2010.

Limbeck, A. and Puxbaum, H.: Organic acids in continental background aerosols, Atmos. Environ., 33, 1847-1852, 1999.

Limbeck, A., Kraxner, Y., and Puxbaum, H.: Gas to particle distribution of low molecular weight dicarboxylic acids at two different sites in central Europe (Austria), J. Aeros. Sci., 36, 991-1005, doi:10.1016/j.jaerosci.2004.11.013, 2005.

Mader, B. T., Yu, J. Z., Xu, J. H., Li, Q. F., Wu, W. S., Flagan, R. C., and Seinfeld, J. H.: Molecular composition of the water-soluble fraction of atmospheric carbonaceous aerosols collected during ACE-Asia, J. Geophys. Res., 109, D06206, doi:10.1029/2003JD004105, 2004.

Martinelango, P. K., Dasgupta, P. K., and Al-Horr, R. S.: Atmospheric production of oxalic acid/oxalate and nitric acid/nitrate in the Tampa Bay airshed: Parallel pathways, Atmos. Environ. 41, 4258-4269, 2007.

Matsunaga, S., Mochida, M., and Kawamura, K.: Growth of organic aerosols by biogenic semi-volatile carbonyls in the forestall atmosphere, Atmos. Environ., 37, 2045-2050, 2003.

Mihalopoulos, N., Stephanou, E., Kanakidou, M., Pilitsidis, S., and Bousquet, P.: Troposheric aerosol ionic composition above the Eastern Mediterranean area, Tellus 49B, 314-326, 1997.

Miyazaki, Y., Aggarwal, S. G., Singh, K., Gupta, P. K., and Kawamura, K: Dicarboxylic acids and water-soluble organic carbon in aerosols in New Delhi, India, in winter: Characteristics and formation processes, J. Geophys. Res., 114, D19206, doi:10.1029/2009JD011790, 2009.

Miyazaki, Y., Kawamura, K., and Sawano, M.: Size distributions and chemical characterization of water soluble organic aerosols over the western North Pacific in summer, J. Geophys. Res., 115, D23210, doi:10.1029/2010JD014439, 2010.

Mul̈uler, K., van Pinxteren, D., Plewka, A., Svrcina, B., Kramberger, H., Hofmann, D., Bachmann, K., and Herrmann, H.: Aerosol characterisation at the FEBUKO upwind station Goldlauter (II): Detailed organic chemical characterization, Atmos. Environ. 39, 4219-4231, 2005.

Myriokefalitakis, S., Vrekoussis, M., Tsigaridis, K., Wittrock, F., Richter, A., Brühl, C., Volkamer, R., Burrows, J. P., and Kanakidou, M.: The influence of natural and anthropogenic secondary sources on the glyoxal global distribution, Atmos. Chem. Phys., 8, 4965-4981, doi:10.5194/acp-8-4965-2008, 2008.

Myriokefalitakis, S., Vignati, E., Tsigaridis, K., Papadimas, C., Sciare J., Mihalopoulos, N., Facchini, M.C., Rinaldi, M., Dentener, F.J., Ceburnis, D., Hatzianastasiou, N., O’Dowd, C.D., van Weele, M., Kanakidou, M.: Global modelling of the oceanic source of organic aerosols, Adv. Meteorol., 2010, 939171, 16 pp., doi:10.1155/2010/939171, 2010.

Nenes, A., Pandis, S. N., and Pilinis, C.: ISORROPIA: A new thermodynamic equilibrium model for multiphase multicomponent inorganic aerosols, Aquat. Geochem., 4, 123-152, 1998.

Neususs, C., Gnauk, T., Plewka, A., Herrmann, H., and Quinn, P. K.: Carbonaceous aerosol over the Indian Ocean: OC/EC fractions and selected specifications from size segregated onboard samples, J. Geophys. Res., 107, 8031, doi:10.1029/2001JD000327, 2002.

Norton, R. B., Roberts, J. M., and Huebert, B. J.: Tropospheric oxalate, Geophys. Res. Lett., 10, 517-520, doi:10.1029/GL010i007p00517, 1983.

Noziere, B., Dziedzic, P., and Cordova, A.: Products and Kinetics of the Liquid-Phase Reaction of Glyoxal Catalyzed by Ammonium Ions $\left(\mathrm{NH}_{4}^{+}\right)$, J. Phys. Chem. A., 113, 231-237, doi:10.1021/jp8078293, 2009.

Oliveira, T. S., Pio, C. A., Alves, C. A., Silvestre, A. J. D., Evtyugina, M., Afonso, J. V., Fialho, P., Legrand, M., Puxbaum, H., and Gelencsér, A.: Seasonal variation of particulate lipophilic organic compounds at nonurban sites in Europe, J. Geophys. Res., 112, D23S09, doi:10.1029/2007JD008504, 2007.

Pavuluri, C. M., Kawamura, K., and Swaminathan, T.: Watersoluble organic carbon, dicarboxylic acids, ketoacids, and $\alpha$ dicarbonyls in the tropical Indian aerosols, J, Geophys. Res., 115, D11302, doi:10.1029/2009JD012661, 2010.

Perri, M. J., Seitzinger, S., and Turpin, B. J.: Secondary organic aerosol production from aqueous photooxidation of glycolaldehyde: Laboratory experiments, Atmos. Environ., 43, 1487-1497, 2009.

Pio, C.A., Legrand, M., Oliveira, T., Afonso, J., Santos, C., Caseiro, A., Fialho, P.,Barata, F., Puxbaum, H., Sanchez-Ochoa, A., Kasper-Giebl, A., Gelencser, A., Preunkert, S., and Schock, M.: Climatology of aerosol composition (organic versus inorganic) at nonurban sites on a west-east transect across Europe, J. Geophys. Res., 112, D23S02, doi:10.1029/2006JD008038, 2007.

Plewka, A., Gnauk, T., Bruggemann, E., and Herrmann, H.: Biogenic contributions to the chemical composition of airborne particles in a coniferous forest in Germany, Atmos. Environ., 40, 103-115, 2006.

Pruppacher, H. R. and Jaenicke, R.: The processing of water vapor and aerosols by atmospheric clouds, a global estimate, Atmos. Res., 38, 283-295, 1995.

Puxbaum, H., Rendl, J., Allabashi, R., Otter, L., and Scholes, M. C.: Mass balance of the atmospheric aerosol in a South African subtropical savanna (Nylsvley, May 1997), J. Geophys. Res., 105, 20 697-20 706, 2000.

Pye, H. O. T. and Seinfeld, J. H.: A global perspective on aerosol from low-volatility organic compounds, Atmos. Chem. Phys., 10, 4377-4401, doi:10.5194/acp-10-4377-2010, 2010.

Reichard, P. U., Kraemer, S. M., Frazier, S. W., and Kretzschmar, R.: Goethite dissolution in the presence of phytosiderophores: rates, mechanisms, and the synergistic effect of oxalate, Plant 
Soil, 276, 115-132, doi:10.1007/s11104-005-3504-9, 2005.

Ruellan, S., Cachier, H., Gaudichet, A., Masclet, P., and Lacaux, J.P.: Airborne aerosols over central Africa during the experiment for regional sources and sinks of oxidants (EXPRESSO), J. Geophys. Res., 104(30), 673-30 690, 1999.

Robinson, A. L., Donahue, N. M., Shrivastava, M. K., Weitkamp, E. A., Sage, A. M., Grieshop, A. P., Lane, T. E., Pierce, J. R., and Pandis, S. N.: Rethinking Organic Aerosols: Semivolatile Emissions and Photochemical Aging, Science, 315, 1259, doi:10.1126/science.1133061, 2007.

Saarnio, K., Aurela, M., Timonen, H., Saarikoski, S., Teinilä, K., Mäkelä, T., Sofiev, M., Koskinen, J., Aalto, P. P., Kulmala, M., Kukkonen, J., and Hillamo, R.: Chemical composition of fine particles in fresh smoke plumes from boreal wild-land fires in Europe, Sci. Total Environ., 408, 2527-2542, 2010.

Schwartz, S. E.: Mass-transport considerations pertinent to aqueous phase reactions of gases on liquid water clouds, in Chemistry of Multiphase Atmospheric Systems, NATO ASI Ser., edited by: Jaeschke, W., Springer, Berlin, Germany, 1986.

Schmidl, C., Marr, I. L. Caseiro, A., Kotianova, P., Berner, A., Bauer, H., Kasper-Giebl, A., and Puxbaum, H.: Chemical characterisation of fine particle emissions from wood stove combustion of common woods growing in mid-European Alpine regions, Atmos. Environ., 42, 126-141, 2008.

Sciare, J., Oikonomou, K., Favez, O., Liakakou, E., Markaki, Z., Cachier, H., and Mihalopoulos, N.: Long-term measurements of carbonaceous aerosols in the Eastern Mediterranean: evidence of long-range transport of biomass burning, Atmos. Chem. Phys., 8, 5551-5563, doi:10.5194/acp-8-5551-2008, 2008.

Sciare, J., Favez, O., Sarda-Estève, R., Oikonomou, K., Cachier, H., Kazan, V.: Long-term observations of carbonaceous aerosols in the Austral Ocean atmosphere: Evidence of a biogenic marine organic source, J. Geophys. Res., 114, D15302, doi:10.1029/2009JD011998, 2009.

Seinfeld, J. H. and Pandis, S. N.: Atmospheric Chemistry and Physics: From Air Pollution to Climate Change, A WileyInterscience publication, USA, 1998.

Sempéré, R. and Kawamura, K.: Comparative distributions of dicarboxylic acids and related polar compounds in snow, rain and aerosols from urban atmosphere, Atmos. Environ. 28, 449-459, 1994.

Simpson, D., Yttri, K. E., Klimont, Z., Kupiainen, K., Caseiro, A., Gelencsér, A., Pio, C., Puxbaum, H., and Legrand, M.: Modeling carbonaceous aerosol over Europe: Analysis of the CARBOSOL and EMEP EC/OC campaigns, J. Geophys. Res., 112, D23S14, doi:10.1029/2006JD008158, 2007.

Sinreich, R., Coburn, S., Dix, B., and Volkamer, R.: Ship-based detection of glyoxal over the remote tropical Pacific Ocean, Atmos. Chem. Phys., 10, 11359-11371, doi:10.5194/acp-1011359-2010, 2010.

Sorooshian, A., Varutbangkul, V., Brechtel, F. J., Ervens, B., Feingold, J., Bahreini, R., Murphy, S. M., Holloway, J. S., Atlas, E. L., Buzorius, G., Jonsson, H., Flagan, R. C., Seinfeld, J. H.: Oxalic acid in clear and cloudy atmospheres: Analysis of data from International Consortium for Atmospheric Research on Transport and Transformation 2004, J. Geophys. Res., 111, D23S45, doi:10.1029/2005JD006880, 2006.

Sorooshian, A., Ng, N. L., Chan, A. W. H., Feingold, G., Flagan, R. C., and Seinfeld, J. H.: Particulate organic acids and overall water-soluble aerosol composition measurements from the 2006 Gulf of Mexico Atmospheric Composition and Climate Study (GoMACCS), J. Geophys. Res., 112, D13201, doi:10.1029/2007JD008537, 2007.

Sorooshian, A., Murphy, S. M, Hersey, S., Bahreini, R., Jonsson, H., Flagan, R. C., and Seinfeld, J. H.: Constraining the contribution of organic acids and AMS $\mathrm{m} / \mathrm{z} 44$ to the organic aerosol budget: On the importance of meteorology, aerosol hygroscopicity, and region, Geophys. Res. Lett., 37, L21807, doi:10.1029/2010GL044951, 2010.

Souza, S. R., Vasconcellos, P. C., and Carvalho, L. R. F.: Low molecular weight carboxylic acids in an urban atmosphere: Winter measurements in Sao Paulo City, Brazil, Atmos. Environ., 33, 2563-2574, 1999.

Stavrakou, T., Mller, J.-F., De Smedt, I., Van Roozendael, M., Kanakidou, M., Vrekoussis, M., Wittrock, F., Richter, A., and Burrows, J. P.: The continental source of glyoxal estimated by the synergistic use of spaceborne measurements and inverse modelling, Atmos. Chem. Phys., 9, 8431-8446, doi:10.5194/acp-9-8431-2009, 2009.

Stone, E. A., Hedman, C. J., Zhou, J., Mieritz, M., and Schauer, J. $\mathrm{J} .:$ Insights into the nature of secondary organic aerosol in Mexico City during the MILAGRO experiment 2006, Atmos. Environ., 44, 312-319, 2010.

Sun, J. and Ariya, P.A.: Atmospheric organic and bio-aerosols as cloud condensation nuclei (CCN): A review, Atmos. Environ. 40, 795-820, 2006.

Talbot, R. W., Andreae M. O., Andreae, T. W., and Harriss, R. C.: Regional aerosol chemistry of the Amazon basin during the dry season, J. Geophys. Res., 93, 1499-1508, 1988.

Tan, Y., Perri, M. J., Seitzinger, S. P., and Turpin, B. J.: Effects of precursor concentration and acidic sulfate in aqueous glyoxal-oh radical oxidation and implications for secondary organic aerosol, Environ. Sci. Technol., 43, 8105-8112, doi:10.1021/es901742f, 2009.

Topping, D., Coe, H., McFiggans, G., Burgess, R., Allan, J., Alfarra, M.R., Bower, K., Choularton, T. W. Decesari, S., and Facchini, M. C.: Aerosol chemical characteristics from sampling conducted on the Island of Jeju, Korea during ACE Asia, Atmos. Environ., 38, 2111-2123, 2004.

Tsigaridis, K. and Kanakidou, M.: Secondary organic aerosol importance in the future atmosphere, Atmos. Environ., 41, 46824692, doi:10.1016/j.atmosenv.2007.03.045, 2007.

Tsigaridis, K. and Kanakidou, M.: Global modelling of secondary organic aerosol in the troposphere: a sensitivity analysis, Atmos. Chem. Phys., 3, 1849-1869, doi:10.5194/acp-3-1849-2003, 2003.

Tsigaridis, K., Krol, M., Dentener, F. J., Balkanski, Y., Lathière, J., Metzger, S., Hauglustaine, D. A., and Kanakidou, M.: Change in global aerosol composition since preindustrial times, Atmos. Chem. Phys., 6, 5143-5162, doi:10.5194/acp-6-5143-2006, 2006.

van der Werf, G. R., Randerson, J. T., Giglio, L., Collatz, G. J., Kasibhatla, P. S., and Arellano Jr., A. F.: Interannual variability in global biomass burning emissions from 1997 to 2004, Atmos. Chem. Phys., 6, 3423-3441, doi:10.5194/acp-6-3423-2006, 2006.

Van Noije, T. P. C., van Eskes, H. J., van Weele, M., and van Velthoven, P. F. J.: Implications of the enhanced Brewer-Dobson 
circulation in European Centre for Medium-Range Weather Forecasts reanalysis ERA-40 for the stratosphere-troposphere exchange of ozone in global chemistry transport models, J. Geophys. Res., 109, D19308, doi:10.1029/2004JD004586, 2004.

Viana, M., Lopez, J. M., Querol, X., Alastuey, A., Garcia-Gaciob, A. D., Blanco-Heras, G., Lopez-Mahia, P., Pineiro-Iglesias, M., Sanz, M. J. Sanz, F., Chi, X., and Maenhaut, W.: Tracers and impact of open burning of rice straw residues on PM in Eastern Spain, Atmos. Environ., 42, 1941-1957, 2008.

Vignati, E., Facchini, M. C., Rinaldi, M., Scannell, C., Ceburnis, D., Sciare, J., Kanakidou, M., Myriokefalitakis, S., Dentener, F., and O'Dowd, C.D.: Global scale emission and distribution of seaspray aerosol: sea-salt and organic enrichment, Atmos. Environ., 44, 5, 670-677, doi:10.1016/j.atmosenv.2009.11.013, 2010.

Volkamer, R., Jimenez, J. L., Martini, F. S., Dzepina,K., Zhang, Q., Salcedo, D., Molina, L. T., Worsnop, D. R., and Molina, M. J.: Secondary organic aerosol formation from anthropogenic air pollution: Rapid and higher than expected, Geophys. Res. Let., 33, L17811, doi:10.1029/2006GL026899, 2006.

Volkamer, R., San Martini, F., Salcedo, D., Molina, L. T., Jimenez, J. L., and Molina, M. J.: A Missing Sink for Gas-Phase Glyoxal in Mexico City: Formation of Secondary Organic Aerosol, Geophys. Res. Lett., 34, L19807, doi:10.1029/2007GL030752, 2007.

Volkamer, R., Ziemann, P. J., and Molina, M. J.: Secondary Organic Aerosol Formation from Acetylene $\left(\mathrm{C}_{2} \mathrm{H}_{2}\right)$ : seed effect on SOA yields due to organic photochemistry in the aerosol aqueous phase, Atmos. Chem. Phys., 9, 1907-1928, doi:10.5194/acp9-1907-2009, 2009.

Volkamer, R., Coburn, S. C., Dix, B. K., and Sinreich, R.: The Eastern Pacific Ocean is a source for short lived atmospheric gases: glyoxal and iodine oxide, CLIVAR Exchanges, 15, 30-33, 2010.

Wang, G., Xie, M., Hu, S., Gao, S., Tachibana, E., and Kawamura, K.: Dicarboxylic acids, metals and isotopic compositions of $\mathrm{C}$ and $\mathrm{N}$ in atmospheric aerosols from inland China: implications for dust and coal burning emission and secondary aerosol formation, Atmos. Chem. Phys., 10, 6087-6096, doi:10.5194/acp-106087-2010, 2010.
Warneck, P.: In-cloud chemistry opens pathway to the formation of oxalic acid in the marine atmosphere, Atmos. Environ., 37, 2423-2427, 2003.

Wittrock, F., Richter, A., Oetjen, H., Burrows, J. P., Kanakidou, M., Myriokefalitakis, S., Volkamer, R., Beirle, S., Platt, U., and Wagner, T.: Simultaneous Global Observations of Glyoxal and Formaldehyde from Space, Geophys. Res. Lett., 33, L16804, doi:10.1029/2006GL026310, 2006.

Yamasoe, M. A., Artaxo, P., Miguel, A. H., and Allen, A. G.: Chemical composition of aerosol particles from direct emissions of vegetation fires in the Amazon Basin: water-soluble species and trace elements, Atmos. Environ., 34, 1641-1653, 2000.

Yang, F., Chen, H., Wang, X., Yang, X., Du, J., and Chen, J.,: Single particle mass spectrometry of oxalic acid in ambient aerosols in Shanghai: Mixing state and formation mechanism, Atmos. Environ., 43, 3876-3882, doi:10.1016/j.atmosenv.2009.05.002, 2009.

Yu, J. Z., Huang, X.-F., Xu, J., and Hu, M.: When Aerosol Sulfate Goes Up, So Does Oxalate: Implication for the Formation Mechanisms of Oxalate, Environ. Sci. Technol. 39, 128-133, doi:10.1021/es049559f, 2005.

Yu, S.: Role of organic acids (formic, acetic, pyruvic and oxalic) in the formation of cloud condensation nuclei $(\mathrm{CCN})$ : a review, Atmos. Res., 53, 185-217, 2000.

Zhang, Q., Jimenez, J. L., Canagaratna, M. R., Allan, J. D., Coe, H., Ulbrich, I., Alfarra, M. R., Takami, A., Middlebrook, A. M., Sun, Y. L., Dzepina, K., Dunlea, E., Docherty, K., DeCarlo, P. F. , Salcedo, D., Onasch, T., Jayne, J. T. , Miyoshi, T., Shimono, A., Hatakeyama, S., Takegawa, N., Kondo, Y., Schneider, J., Drewnick, F., Borrmann, S., Weimer, S., Demerjian, K., Williams, P., Bower, K., Bahreini, R., Cottrell, L., Griffin, R. J., Rautiainen, J., Sun, J. Y., Zhang, Y. M., and Worsnop, D. R.: Ubiquity and dominance of oxygenated species in organic aerosols in anthropogenically-influenced Northern Hemisphere midlatitudes, Geophys. Res. Lett., 34, L13801, doi:10.1029/2007GL029979, 2007. 